\title{
Modified Cholinesterase Technology in the Construction of Biosensors for Organophosphorus Nerve Agents and Pesticides Detection
}

\author{
Monika Hoskovcová and Zbyněk Kobliha \\ University of Defence, NBC Defence Institute \\ Czech Republic
}

\section{Introduction}

Organophosphorus compounds are a wide-spread group of agents which can be used among others as pesticides, especially insecticides, or chemical warfare agents. These extremely toxic compounds irreversibly inhibit the enzymes of hydrolases class, which have the catalytic capability of hydrolyzing their specific neurotransmitters in synaptic clefts of the nervous system. The organophosphorus pesticides and carbamates are agents used in agriculture very often, because of their relatively low stability. Many of them, however, have very high acute toxicity for warm-blooded animals.

The group of organophosphorus compounds also includes nerve agents with their dominant position among chemical warfare agents. The discovery of their effects was made more or less accidentally in the 30-ies of the last century during the research of fluoroorganic compounds in IG Farben, a German company, by Dr. Gerhard Schrader. The first synthesized agent was ethyl-(dimethylamido)phosphorocyanidate, designated as trilon 83 or tabun. However, it was not the first known agent with a cholinergic effect. Back in 1854 a French chemist, Phillip de Clermont, synthesized the first organophosphate - tetraethyl pyrophosphate (de Clermont, 1855, as cited in Holmstedt, 2000). Gradually more agents with N-P, P-CN or C-F bonds were synthesized in order to produce insecticides and later also nerve agents (Holmstedt, 2000). After verifying the effects of tabun for warm-blooded animals, a synthesis of other, even more toxic, agents followed (Pitschmann, 1999). In 1939 isopropyl-methylphosphonofluoridate was discovered, also called trilon 46 or sarin, and in 1944 (3,3-dimethylbutane-2-yl)-methylphosphonofluoridate, the so-called soman, followed. These agents belong to the so-called G-series of nerve agents. The origin of a new V-series dates back to the end of 50 -ies. This group of agents has increased toxicity when penetrating the skin. The principal representative is $S$-[2-(diisopropylamino)ethyl]-O-ethylmethylphosphonothioate, also known as VX, and S-[2-(diethylamino)ethyl]-O-isobutylmethylphosphonothioate with the code designation R-33. In the 70-ies up to 90-ies another group of nerve agents was discovered in the former USSR within the so-called Foliant program. These are compounds based on phosphorylated and phosphonylated oximes and amidases. According to unauthorized sources they reach at least the toxicity of VX, some are even 5 to 8 times more toxic. In a case like this there could be a problem with their detection. 
The limit of detection of the most of current technical means is, with the exception of means based on biochemical cholinesterase reaction, unsatisfactory.

The inhibition of enzyme efficacy happens even at very low concentrations of nerve agents or pesticides. Even trace amounts of these agents can represent a considerable hazard to health for living organisms. Detection through the biochemical method is characterized by high sensitivity and enables setting of about $1.10^{-5}-1.10^{-7} \mathrm{mg} \cdot \mathrm{ml}^{-1}$ in the solution or 11 of air depending on the type of inhibitor. This sensitivity is up to five times higher compared to methods based on chemical or physical principle (Halámek et al., 2009). For this reason a number of biosensors, which provide a suitable alternative to classical analytical methods, has been developed based on the biochemical reaction. It is an analytical device which consists of a biologically active material such as an enzyme, an antibody or a binding protein and a converter which converts the biochemical reaction to an output signal which can be quantified. These converters can be based on amperometric, potentiometric, chemiluminescent, piezoelectric or optical principles and on a semiconductor or an ionselective effect of transistor techniques. Their development has been important especially in the last two decades. They meet the demands for a quick and cheap analysis with high sensitivity (Kenar, 2010; Rekha et al., 2000).

This chapter deals with a general overview and characteristics of methods for detection and identification of nerve agents and pesticides based on the cholinesterase reaction and its modifications. It shows some practical applications of biosensors and indicates some new trends in the field leading to increasing the selectivity for identification of individual nerve agents.

\section{Cholinesterases}

The hydrolases, which are used for the construction of biosensors, are basically two, acetylcholinesterase (AChE, EC 3.1.1.7), also called a genuine or specific cholinesterase, and butyrylcholinesterase (BuChE, EC 3.1.1.8), the so-called false or also nonspecific cholinesterase. The task of ACHE is the hydrolysis of a specific neurotransmitter acetylcholine $(\mathrm{ACh})$ in a neurosynaptic cleft and thus the termination of irritating cholinergic receptors or a neuromuscular junction. The physiological importance of BuCHE in a body is not, compared to AChE, so essential. Its physiological function has not been exactly identified yet (Masson et al., 2009). However, it has been found out that it plays some role in metabolism of local anaesthetics, novocaine and cocaine (Carmona et al., 2000). Its specific substrate is butyrylcholine $(\mathrm{BuCh})$. Besides natural substrates also a synthetic substrate, e.g. 4-aminophenyl acetate, can be used for both enzymes. Both enzymes basically have a similar three-dimensional structure but there is a difference in their substrate specificity and sensitivity to inhibitors (Hanin \& Dudas, 2001). Hydrolytic reactions catalyzed by cholinesterases proceed in a narrow space of the active center where the socalled esteratic and anionic site can be found. The esteratic site is made up of the so-called catalytic triad a part of which is the serine residuum which reacts with the substrate but also with organophosphates. The presence of substrate in the active center of AChE stabilizes the configuration of the catalytic triad. The size of the substrate molecule and its positive charge at the nitrogen atom influence the size of the bond to anionic site. It has been experimentally found out that this bond is reduced by relocating the positive charge (Kua et al., 2002). The decomposition of a neurotransmitter results in ACh bond to the active site of AChE enzyme which is placed in the hole of the active center, about 20 Á deep (Sussman et al., 1991). The 
tertiary nitrogen in ACh molecule is bonded to the anionic site represented by a glutamate ion. The oxygen from the acyl part of the substrate molecule is bonded in the oxy anion hole. Thereby the ACh molecule is anchored in the active center. The hydroxyl serine group, which binds the acetyl part of ACh, participates in splitting of ester. Then the substrate is split up into acetyl and choline. The effect of hydrolysis by means of a water molecule, present in the cleft of the active center, causes spontaneous reconstruction of enzyme activity. An acylating group, which can be active within another choline acetylation, splits off from the enzyme molecule (Somani et al., 1992). The mechanism of acetylcholine hydrolysis catalyzed by the acetylcholinesterase enzyme is shown in the reaction scheme 1 .

$$
\mathrm{CH}_{3} \mathrm{C}(\mathrm{O}) \mathrm{OCH}_{2} \mathrm{CH}_{2} \stackrel{+}{\mathrm{N}}\left(\mathrm{CH}_{3}\right)_{3}+\mathrm{H}_{2} \mathrm{O} \stackrel{\mathrm{AChE}}{\longrightarrow} \mathrm{CH}_{3} \mathrm{COOH}+\mathrm{HOCH}_{2} \mathrm{CH}_{2} \stackrel{+}{\mathrm{N}}\left(\mathrm{CH}_{3}\right)_{3}
$$

Reaction scheme 1. Mechanism of acetylcholine hydrolysis catalyzed by the acetylcholinesterase enzyme.

Nerve agents, even at very low concentrations, inhibit their hydrolytic capacity through a bond in this active center. The inhibition takes place in several steps, as shown in the reaction scheme 2. In the first one the inhibitor is bonded to a hydroxyl serine group in the esteratic center of AChE. Thus the reversible enzyme-inhibitor complex arises. Further serin is covalently phosphorylated. An electronegative leaving group is released from the molecule of organophosphorus toxic agent. This bond is still reversible. A competing process is the ageing of $\mathrm{AChE}$, the phosphorylated $\mathrm{AChE}$ switches to its dealkylated form. It is a process where the alcohol is split off by means of water and the alkoxyl group bonded to phosphor is replaced by the hydroxyl group. This state is irreversible. The result of enzyme inactivation is accumulation of acetylcholine in the nerve ending and development of toxic exposures demonstrated in the form of nicotine, muscarinic and central effects (Watson et al., 2009).
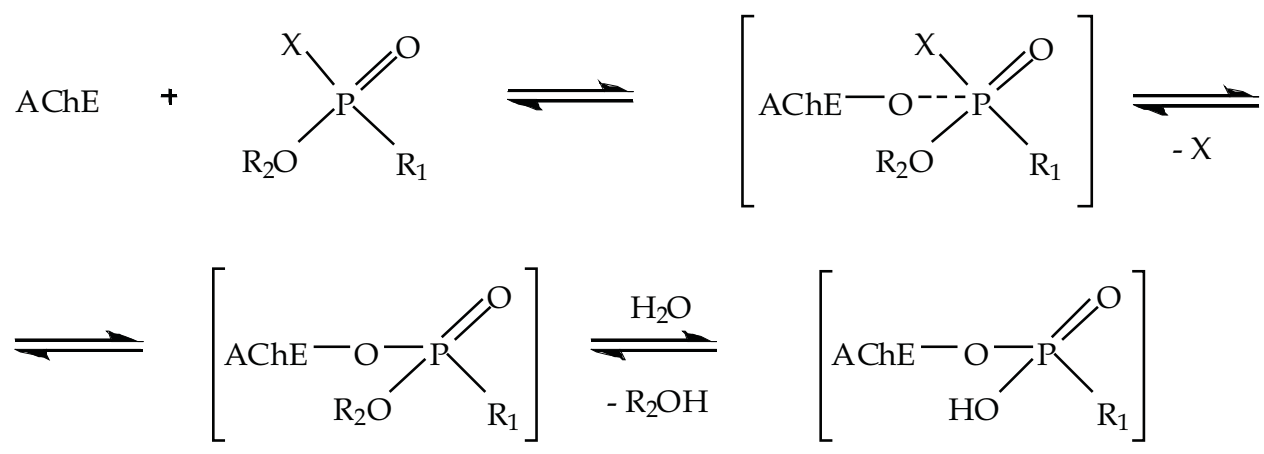

Reaction scheme 2. Mechanism of inhibition of the acetylcholinesterase enzyme.

The enzyme inhibition will prove itself in reducing its activity depending on the degree of inactivation. This reduction can be measured objectively and it is a significant factor for the construction of biosensors. The basis for measuring the enzyme activity is the reaction with a suitable substrate. AChE catalyzes the hydrolysis of acetylcholine substrate, or its sulfur isoester - acetylthiocholine; BuChE hydrolyzes then the catalysis of butyrylcholine or butyrylthiocholine. Subsequently you can observe the decrease in substrate, the increase in 
products or an unreacted substrate. Quite usual is the observation of concentration of hydrolysis products, i.e. an appropriate acid or choline. We shall not forget $\mathrm{pH}$-metric methods based on the measurement of concentration of an arising acid in combination with acid-base indicators and buffers or finished with alkalimetric titration or also with determination of $\mathrm{CO}_{2}$ (Tomeček \& Matoušek, 1961). The methods of manometric, fluorometric, colorimetric and spectrophotometric evaluation or electrochemical methods such as potentiometry, amperometry, coulometry or voltammetric indication are also worth mentioning. Some benefits can be seen in using the so-called chromogenous substrates which brought modification and expansion of possibilities of the cholinesterase method. Those are used for example with photometric methods; we observe changes in coloring caused by the reaction of hydrolysis products with chromogenous reagents.

The advantage of enzymatic methods for identification of organophosphorus compounds is their high sensitivity and specificity. The demands on making an analysis are, compared to common analytical methods, lower as well as their cost. For these reasons they are applied more and more often, e.g. when checking the environment contamination.

The detection of nerve agents and pesticides based on organophosphates can be done not only on the basis of choline esterases but there is also a new trend, a non-inhibitory method based on organophosphate hydrolase (OPH, EC 3.1.8.1) or organophosphorus acid anhydrolase (OPAA, EC 3.1.8.2). OPH hydrolyses compounds with P-O, P-F, P-S and P-CN bonds. There were tests of some pesticides, such as paraoxon and parathion, and nerve agents, e.g. sarin or VX (Donarski et al., 1989; as cited in Wang et al., 1999; Joshi et al., 2006). So the organophosphorus compounds act for $\mathrm{OPH}$ as a substrate. These types of biosensors offer, same as the cholinesterase ones, using optical, fluorescent, potentiometric or amperometric converters (Karnati et al., 2007; Mulchandani, et al. 1999a, 1999b; Rogers et al., 1999; Wang et al., 2003). Also a field version for in-situ monitoring has been developed (Wang et al., 1999; Mulchandani et al., 2001). The OPAA enzyme selectively hydrolyses organophosphorus compounds containing the P-F bond; for compounds with other common bonds occurring in nerve agents and pesticides the substrate activity is low. A biosensor with this enzyme was successfully tested for example for diisopropylfluorophosphate. Besides measuring of $\mathrm{pH}$ changes using a glass electrode, $\mathrm{pH}$-sensitive field effect transistor ( $\mathrm{pH}-\mathrm{FET}$ ), also an ion-selective electrode for fluoride ions can be used (Simonian et al., 2001).

\section{Cholinesterase biosensors}

The inhibitory reactions can proceed in the solution; a disadvantage, however, is the limited use of enzyme and thus also the increase of cost or enzyme immobilization onto a suitable material and connection with an appropriate converter. The first biosensor based on the cholinesterase inhibition through organophosphorus compounds was constructed by G. Guibault back in 1962 (Guibault et al., 1962; as cited in Arduini et al., 2010). Since that time many biosensors have been developed for identification of nerve agents and pesticides.

Cholinesterase biosensors may be classified according to a converter they use. Most often electrochemical converters are used, further piezoelectric and optical converters and surface plasmon resonance (SPR) (Arduini et al., 2010; Lin et al., 2006). This chapter deals particularly with electrochemical and optical methods.

A common disadvantage of cholinesterase biosensors is the irreversible character of inhibition in the course of analysis. In many cases it is impossible to recover a biosensor like 
that and to use it once again. This limits the life of biosensor to $10-15$ identifications. It is necessary to recover the enzyme continuously, which can cause considerable difficulties, especially in field conditions. Some procedures have been developed, for example using nucleophilic reagents, the so-called cholinesterases reactivators (Dăneț et al., 2003; Gulla et al., 2002; Gyurcsányi, et al., 1999; Tušarová et al., 1999) or surface regeneration using selfassemble layers with a piezoelectric biosensor (Makower et al., 2003).

\subsection{Electrochemical biosensors}

Electrochemical methods are based on a potentiometric, amperometric or conductometric method of measurement. Most often amperometric and potentiometric devices are used.

Electrochemical biosensors make use of mono- and multienzymatic systems. The monoenzymatic systems use the above-mentioned AChE or BuChE hydrolases, the bienzymatic ones use then the cholinesterase-choline oxidase (ChE-ChO) system (Rekha et al., 2000), the trienzymatic ones use cholinesterase, cholinoxidase and peroxidase (POD) (Ghindilis et al., 1996).

\subsubsection{Amperometric biosensors}

Amperometric biosensors are the most widely used type of electrochemical sensors and a good substitution for the potentiometric ones. They provide a linear output signal depending on the concentration of analyte. There are several ways how to evaluate the enzyme activity by means of amperometric methods. The first one includes the bienzymatic cholinesterase-cholinoxidase (ChE-ChO) system with an oxygen or peroxide amperometric converter (Campanella, 2007). The choline from the hydrolytic enzyme catalysis is not electrochemically active; that is why cholinoxidase is used by means of which the choline oxidizes to betaine while developing the hydrogen peroxide, as shown in the reaction scheme 3. This results in detection of the occurrence of hydrogen peroxide or oxygen consumption.

$$
\left(\mathrm{CH}_{3}\right)_{3} \stackrel{+}{\mathrm{N}} \mathrm{CH}_{2} \mathrm{CH}_{2} \mathrm{OH}+\mathrm{O}_{2}+\mathrm{H}_{2} \mathrm{O} \stackrel{\mathrm{ChO}}{\longrightarrow}\left(\mathrm{CH}_{3}\right)_{3} \stackrel{+}{\mathrm{N}} \mathrm{CH}_{2} \mathrm{CH}_{2} \mathrm{COOH}+2 \mathrm{H}_{2} \mathrm{O}_{2}
$$

Reaction scheme 3. Reaction mechanism of the bienzymatic amperometric ChE-ChO system.

The second way includes the modification using ACh sulfur isoester, acetylthiocholine, which is electrochemically active (Pohanka, 2009). With applied voltage in the reaction mixture the resulting thiocholine undergoes an oxidation-reduction reaction according to the reaction mechanism in scheme 4 . These systems were tested not only for pesticides and nerve agents but also for toxins with a cholinergic effect (Kandimalla \& Ju, 2006; Pohanka et. al., 2008). Also a bienzymatic amperometric biosensor based on BuChE and sulfhydryl oxidase (SOX) has been developed even if it has not been tested for organophosphorus esterases inhibitors so far. Butyrylthiocholine catalytically hydrolyzes while developing the thiocholine which acts as a SOX substrate in the subsequent oxidation (see the reaction scheme 5). The measurement was made through the subsequent detection of oxygen consumption which is proportional to BuTCh concentration. SOX catalyzes the formation of disulfide bridges between sulfhydryl groups (Teksoy, 2007).

$$
\mathrm{CH}_{3} \mathrm{C}(\mathrm{O}) \mathrm{SCH}_{2} \mathrm{CH}_{2} \stackrel{+}{\mathrm{N}}\left(\mathrm{CH}_{3}\right)_{3}+\mathrm{H}_{2} \mathrm{O} \stackrel{\mathrm{AChE}}{\longrightarrow} \mathrm{CH}_{3} \mathrm{COOH}+\mathrm{HSCH}_{2} \mathrm{CH}_{2} \stackrel{+}{\mathrm{N}} \mathrm{H}\left(\mathrm{CH}_{3}\right)_{3}
$$




$$
2 \mathrm{HSCH}_{2} \mathrm{CH}_{2} \stackrel{+}{\mathrm{N}}\left(\mathrm{CH}_{3}\right)_{3} \stackrel{+410 \mathrm{mV}}{\longrightarrow}\left(\mathrm{CH}_{3}\right)_{3} \stackrel{+}{\mathrm{N}} \mathrm{CH}_{2} \mathrm{CH}_{3}-\mathrm{S}-\mathrm{S}-\mathrm{CH}_{2} \mathrm{CH}_{2} \stackrel{+}{\mathrm{N}}\left(\mathrm{CH}_{3}\right)_{3}+2 \mathrm{H}^{+}+2 \mathrm{e}^{-}
$$

Reaction scheme 4. Reaction mechanism of the enzyme acetylthiocholine hydrolysis and subsequent oxidation through applied voltage.

$$
\begin{gathered}
\mathrm{CH}_{3}\left(\mathrm{CH}_{2}\right)_{2} \mathrm{C}(\mathrm{O}) \mathrm{SCH}_{2} \mathrm{CH}_{2} \stackrel{+}{\mathrm{N}}\left(\mathrm{CH}_{3}\right)_{3}+\mathrm{H}_{2} \mathrm{O} \stackrel{\mathrm{BuChE}}{\mathrm{SOX}} \mathrm{CH}_{3}\left(\mathrm{CH}_{2}\right)_{2} \mathrm{COOH}+\mathrm{HSCH}_{2} \mathrm{CH}_{2} \stackrel{+}{\mathrm{N}}\left(\mathrm{CH}_{3}\right)_{3} \\
2\left(\mathrm{CH}_{3}\right)_{3} \stackrel{+}{\mathrm{N}} \mathrm{CH}_{2} \mathrm{CH}_{2} \mathrm{SH}+\mathrm{O}_{2} \longrightarrow\left(\mathrm{CH}_{3}\right)_{3} \stackrel{+}{\mathrm{N}} \mathrm{CH}_{2} \mathrm{CH}_{3}-\mathrm{S}-\mathrm{S}-\mathrm{CH}_{2} \mathrm{CH}_{2} \stackrel{+}{\mathrm{N}}\left(\mathrm{CH}_{3}\right)_{3}+\mathrm{H}_{2} \mathrm{O}_{2}
\end{gathered}
$$

Reaction scheme 5. Reaction mechanism of the bienzymatic ChE-SOX system.

Besides natural substrates it is possible to use also the synthetic 4-aminophenyl acetate. The enzyme-catalyzed hydrolysis gives rise to an electroactive 4-aminophenol which is oxidized on the electrode surface (see the reaction scheme 6) (La Rosa et al., 1994). The advantage lies in simplicity of using the system with this substrate and a low applied potential.<smiles>CC(=O)Oc1ccc(N)cc1</smiles>

Reaction scheme 6. Reaction mechanism of the enzyme 4-aminophenyl acetate hydrolysis.

As for cholinesterases in amperometric measurements the above-mentioned AChE or $\mathrm{BuChE}$ are used; they hydrolyze the substrate to an appropriate choline (acetyl or butyrylcholine), in case of 4-aminophenyl acetate it is 4-aminophenol and an acid (acetic or butyric). These reactions, however, are complicated by occurrence of byproducts deposited on the electrode or by a spontaneous substrate hydrolysis itself. Limiting is also the necessity of using high working voltage which limits the use of biosensors for samples with electroactive molecules. In case of cholinesterase biosensors it is possible to lower the voltage and interferences of electroactive sample components by means of redox transmitters such as ferophtalocyanine, cobalt phtalocyanine, Prussian blue (ferrihexacyanofferate), 7,7,8,8-tetracyanoquinodimethane (TCNQ) in combination with carbon electrodes, screen electrodes or using the carbon nanotube (CNT) (Arduini et al., 2007; Ciucu et. al., 2003; Hart et al., 1997; Hernandez et al., 2000; Lin et al., 2004; Ricci et al., 2003; Ivanov et al., 2003a; Nunes et al., 2004; Shulga \& Kirchhoff, 2007; Skládal, 1992; Skládal \& Mascini, 1992; Sun \& Wang, 2010; Suprun et al., 2005; Wring et al., 1989) or electrochemical decomposition of the arising peroxide using a gold or platinum amperometric electrode (Yao, 1983).

CNTs are commonly used for electrochemical biosensors. They occur in two forms - singlewalled (SWCNT) and multi-walled (MWCNT). They are characterized by excellent chemical stability, good structural and mechanical properties and electrical conductivity. And these are exactly the qualities which make them an ideal means for construction of biosensors. They provide an improved electrochemical detection of enzymatic-developed thiocholine not only thanks to the reduction of over-voltage but also thanks to higher sensitivity and stability (Liu \& Lin, 2006; Zhang \& Gorski, 2005; as cited in Du et al., 2007). However, they are insoluble in most of the organic solvents and water solutions. Nevertheless, CNT 
biosensors for detection of pesticides with an immobilized enzyme have been developed, e.g. MWCNT with chitosan matrix (Du et al, 2007) or a glass carbon electrode (GCE) modified by MWCNT with chitosan matrix with immobilized AChE (Sun et al., 2010) or a glass electrode modified by CNT for detection of pesticides and nerve agents (Liu et al., 2005).

The principle of thiocholine substrate splitting is used for example by a biosensor with platinum electrode with immobilized $\mathrm{AChE}$ and $\mathrm{Ag} / \mathrm{AgCl}$ reference electrode in the midst of which a potential of $+410 \mathrm{mV}$ is applied (Martorell et al., 1994), at Pt anode with a potential of $+410 \mathrm{mV}$ vs. $\mathrm{Ag} / \mathrm{AgCl}$ (Marty et al., 1993) or Ti-Au-Pt electrode with $+700 \mathrm{mV}$ versus a saturated calomel electrode, etc. Thiocholine is oxidized at the anode. The platinum electrode is not suitable for detection of sulfhydryl compounds because of the necessity of using too high over-voltage. For this reason the aforementioned carbon electrodes are used, chemically modified by cobalt phtalocyanine or other modifiers, which leads to reduction of the applied potential and lowering of interferences caused by electrochemical impurities (Halbert \& Baldwin, 1985; Ciucu \& Baldwin, 1992; as all cited in Ciucu et al., 2003; Skládal, 1992). An ideal tool for monoenzymatic systems based on the acetylthiocholine hydrolysis is also the detection using screen electrodes, for example in connection with cobalt phtalocyanine which transmits the oxidation of thiocholine (Bucur et al., 2005).

Another application makes use of a working electrode with graphite compound and $\mathrm{Ag} / \mathrm{AgCl}$ reference electrode and applied voltage of $+700 \mathrm{mV}$ (Turdean, 2002). The amperometric biosensor for detection of methyl paraoxon, carbofuran and phoxim has been developed based on the modified platinum electrode with immobilized AChE at gold nanoparticles and a silk fibroin.

The hydrogen peroxide can be detected via amperometry at $+650 \mathrm{mV}$ versus the reference $\mathrm{Ag} / \mathrm{AgCl}$ electrode (Andreescu \& Marty, 2006). An approach of a ceramic microelectrode with cholinoxidase for measurement of changes to the extracellular choline with a detection limit of $300 \mathrm{nM}$ and an ability to measure sudden ACh changes in brain and its hydrolysis to choline has been developed (Burmeister et al., 2003; Parikh et al., 2004; Parik et al., 2006; as all cited in Philips, 2005). For detection of organophosphorus pesticides a biosensor has been constructed, containing BuChE and $\mathrm{CHO}$ layered onto a nylon membrane of a hydrogen peroxide electrode (Campanella et al., 1992). Another system is based on detection of oxygen consumption in this reaction using Clark's electrode (Mizutani \& Tsuda, 1982). After enzyme inhibition there is reduction in the production of hydrolytic products and thus also cutting of oxygen consumption which is proportional to the enzyme activity. The disadvantage of this system is the required incubation period and enzyme consumption for every other identification.

An amperometric biosensor, which uses the AChE enzyme and 4-aminophenyl acetate as a substrate, has been described. AChE is immobilized onto a glass carbon electrode (La Rosa et al., 1994; Pariente et al., 1993) or a screen electrode (Andreescu et al., 2002a). The enzymatic-hydrolyzed 4-aminophenol can be detected also via voltametry. The disadvantage of screen electrodes is their low stability in organic solvents because of partial solubility of the printed layer.

In the paper (Mitchell, 2004) a multienzyme biosensor for amperometric detection of ACh and choline (Ch) in vivo is described. This biosensor makes use of $\mathrm{AChE}, \mathrm{ChO}$ and ascorbic acid oxidase (AAO) immobilized onto a platinum-iridium wire with an electropolymer layer Poly(m-(1,3)-phenylenediamine). 
For detection of organophosphorus pesticides and carbamates in water and food a portable amperometric biosensor has been assembled, consisting of a screen electrode with $10 \mathrm{mU}$ of immobilized AChE connected with potentiostat and a portable computer. It enables detection even in a pepper extract (Hildebrandt et al., 2008). Pesticides present in water samples were successfully detected for example by ChE-ChO biosensor through a peroxide electrode (Bernabei et al., 1993) or in real samples in some organic solvents which can influence the enzyme activity (Palchetti et al., 1997). The sensor for detection of organophosphorus pesticides in river, sea and waste water, based on immobilized $\mathrm{ChO}$ and esterase in the solution, uses the $\mathrm{Pt}$ anode vs. $\mathrm{Ag} / \mathrm{AgCl}$ cathode with $+650 \mathrm{mV}$ (Palleschi et al., 1992).

The development of a new technology for immobilization based on a silicate sol-gel matrix enabled creation of very stable AChE biosensors with nanoparticles. For example an AChE amperometric biosensor with gold nanoparticles (AuNP) in sol-gel matrix with a threeelectrode detection system has been developed, including the $\mathrm{Pt}$ wire as an auxiliary electrode, a saturated calomel reference electrode and a modified glass carbon working electrode with AChE, an ATCh substrate. The flow of arising products after the catalytic hydrolysis and substrate oxidation is detected (Du et al., 2008). Further use of the sol-gel technology based on an alternative non-silica material is offered by the AChE biosensor with ZnO matrix and SPE electrodes (Sinha et al., 2010).

Most of the amperometric biosensors are tested for detection of pesticides, less of them for nerve agents. For detection of nerve agents for example a portable biosensor, which is a part of soldier's individual equipment, has been developed (Arduini et al., 2007).

Generally it can be said that the improvement of amperometric biosensors is based on two approaches, i.e. enhancement of the catalytic capacity and transfer of electrons through various modifications of working electrodes and at a lower potential. There is also a description of multisensors for current detection and identification of mixtures of cholinesterase insecticides based on various options of one enzyme (Bachmann \& Schmidt, 1999; Bachmann et al., 2000), various enzymes (Danzer \& Schwedt, 1996; Istamboulie et al., 2009; Kok \& Hasirci, 2004) using Artificial Neural Networks (ANN).

\subsubsection{Potentiometric biosensors}

As it has been already mentioned, an appropriate organic acid arises in the course of hydrolysis, which is the basis for potentiometric measurements. The simplest one is based on detecting the acid increment by means of a $\mathrm{pH}$-metric device with continuous recording. This configuration, however, is not that suitable for the use in field conditions (Miao et al., 2010).

Potentiometric detectors were also constructed for both hydrolases substrates, Ach and $\mathrm{BuCh}$. For this reason they require different substrate sensors - acetylcholine or butyrylcholine selective electrodes which are based on measurement of the redox potential, either with transmitters or without them. Most often, however, we use $\mathrm{pH}$ sensors based on detection of $\mathrm{pH}$ changes, caused by system acidification after hydrolysis (Zhang et al., 2009). Glass $\mathrm{pH}$ electrodes are the basis for potentiometric measurements but they are expensive, fragile and unfit for miniaturization and require conditiation before using. A substitution may be electrodes based on metal, metal/metal oxide or metal oxide - $\mathrm{Au}, \mathrm{Pd} / \mathrm{PdO}, \mathrm{Ir} / \mathrm{IrO}$, $\mathrm{RuO}_{2}$ (Gyurcsányi, et al., 1999; Koncki \& Mascini, 1997; Reybier et al., 2002; Tran-Minh et al., 1990). Furthermore, we use pH ISFET electrodes (Ion-sensitive field effect transistors) which 
represent a sensitive, cheap, available and simple monitoring device suitable for miniaturization (Dzyadevych et al., 2004; Dzyadevych et al., 2006), a light addressable potentiometric sensor (LAPS) and electrodes modified by polymers (Snejdarkova et al. 2004; Ivanov et al., 2003b).

Most biosensors based on the $\mathrm{pH}$ detection are handicapped thanks to an extended signal response and lower substrate sensitivity. The response extension is given by the necessity of perfusing the reaction layer or by membrane strength and permeability. The basic limit of sensitivity of potentiometric electrodes is given by sensitivity of the $\mathrm{pH}$ converter. This jump in potential versus $\mathrm{pH}$ does not mostly exceed $59 \mathrm{mV}$ per $\mathrm{pH}$ unit. The ISFET sensitivity is 44-54 mV/pH (Cara et al., 1985; as cited in Karyakin et al., 1996). The disadvantages can be partially eliminated by various modifications of electrodes. For this purpose for example a potentiometric acetylcholinesterase biosensor with an antimony $\mathrm{pH}$ electrode has been assembled, having - contrary to the glass ones - an easily recoverable surface for immobilization, low electrical stability and variability of shapes and sizes. For the electrode an immobilization technique of covalent cross-linking with glutaraldehyde vapors in the vacuum was used (Gyurcsányi, et al., 1999).

Potentiometric measurements make use of the above-mentioned ion-selective electrodes (ISE) which serve as a polymer matrix for transmission of reagent substances but also as a converter for this type of electrochemical biosensors. In the paper (Ding \& Qin, 2009) there is a presentation of a detection system where the butyrylcholine substrate is released through ISE membrane and thus the activity of BuChE enzyme or its application for detection of the presence of organophosphorus pesticides in the sample is detected. Constantly releasing the substrate under the zero-current conditions from an external solution to a sample solution provides a measurable signal in situ. Detecting the enzyme activity is then a consequence of disturbing the ion flux induced by membrane potential after the enzyme catalysis.

As far as potentiometric substrate sensors for detection of pesticides are concerned, for example a butyrylcholine sensor, placed on a plasticized polyvinyl chloride membrane by a cationic ion exchanger tetrakis (3,5-bis[2-methoxy-hexafluoro-methyl]phenyl) borate, has been described. The advantage is high hydrophobicity of the ion exchanger used. Compared to other biosensors there has been an improvement of potential stability, life cycle and detection limit (Imato \& Ishibashi, 1995). A biosensor of flow injection type for identification of pesticides is described in the paper (Lee et al., 2002). It consists of AChE immobilized onto controlled porous glass and of a detector with tubular $\mathrm{H}^{+}$of a selective membrane electrode. The organophosphate is oxidized, which leads to increasing the sensitivity of cholinesterase biosensors. Oxidized forms show a higher inhibitory activity.

The potentiometric system without transmitters uses the peroxidase enzyme. The peroxidase (POD) catalyzes the reaction of the arising peroxide through electro-reduction by a mechanism of direct electron transfer from an electrode to a substrate molecule through the active enzyme site (Ghindilis et al., 1996; Ghindilis et al., 1997). This principle was used to test the screen enzyme electrode for detection of organophosphorus pesticides. ChE along with $\mathrm{CHO}$ and POD are co-immobilized on the electrode surface. The enzyme activity is specified based on individual enzymatic reactions, i.e. butyrylcholine hydrolysis to choline, choline oxidation and peroxide formation, and peroxide electro-reduction by means of POD according to the reaction scheme 7 (Espinosa et al., 1999).

Even the potentiometric biosensors can be used to monitor waste substances in the living environment, for example in waste waters (Espinosa et al., 1999; Evtugyn et al., 1997). 


$$
\begin{gathered}
\text { choline }+\mathrm{O}_{2} \stackrel{\text { ChO }}{\longrightarrow} \text { betaine }+\mathrm{H}_{2} \mathrm{O}_{2} \\
\mathrm{H}_{2} \mathrm{O}_{2}+2 \mathrm{e}^{-}+2 \mathrm{H}^{+} \stackrel{\mathrm{POD}}{\longrightarrow}+2 \mathrm{H}_{2} \mathrm{O}
\end{gathered}
$$

Reaction scheme 7. Reaction mechanism of the POD detector.

Over fifty years there has been a research conducted in the field of reactivation of inhibited cholinesterases in vitro and in vivo. For this purpose the so-called reactivators are practically used - strong nucleophilic reagents which recover the function of an inhibited enzyme. The compounds based on mono- and bispyridinium aldoximes or ketoximes proved to be efficient. Based on this also the potentiometric sensor was built up. It works on a principle of the reaction of ketoxime and organophosphorus chemical warfare agent under the development of phosphorylated ketoxime and separation of the leaving group (here $\mathrm{CN}^{-}$ ). The cyanide ion is detected by a silver electrode (Moll et al., 1976; as cited in Oh \& Masel, 2007). Later on this system was reevaluated and optimized not only for organophosphates containing a cyanide group in their structure but also for their simulators using the cyanide ion-selective electrode (Oh \& Masel, 2007).

When comparing amperometric and potentiometric sensors, the amperometric ones are rated as quicker and more sensitive. The potentiometric ones, however, are simpler and more suitable for a field analysis.

\subsubsection{Conductometric biosensors}

The conductometric measurement is based on measuring the conductivity changes which are directly proportional to the occurrence of ions in the measured solution (Dzyadevych et al., 2005). The conductometric biosensors have a big advantage because they do not require the reference electrode and the converter provides the possibility of miniaturization (Miao et al., 2010).

It is impossible to analyze various mixtures of analytes in real samples using just one biosensor type. This problem led to construction of the so-called multibiosensor. For this purpose two converters were linked - the potentiometric one with a $\mathrm{pH}$-sensitive transistor and the conductometric one with thin-films interdigitated electrodes, and three enzymes urease, $\mathrm{AChE}$ and $\mathrm{BuChE}$. This group enables simultaneous identification of some heavy metals and pesticides. Working parameters and experimental conditions are similar as in the case of individual sensors. The result of hydrolytic reactions is the urease consumption or proton production (with $\mathrm{AChE}$ and $\mathrm{BuChE}$ ), which causes the increase in $\mathrm{pH}$ and changes to conductivity at membranes with a subsequent possibility of potentiometric or conductometric way of detection. This system represents a simple way of measurement and it is applicable for the control of drinking water (Arkhypova et al., 2001).

\subsection{Optical biosensors}

\subsubsection{Colorimetric and spectrophotometric biosensors}

Probably the first colorimetric method is Hestrin's quantitative method for identification of an unreacted ACh and esters similar to it. The identification is based on reaction of ACh with hydroxylamine in the alkaline environment in the presence of ferric chloride when the hydroxylamine reacts with ACh while producing the acetylhydroxamic acid and developing the brown-purple complex of ACh-acetylhydroxamic product which can be identified via spectrophotometry at $540 \mathrm{~m} \mu$ (Hestrin, 1949). 
One of the oldest procedures for detection of the presence of nerve agents is measuring the degree of inhibition of cholinesterases using a chromogenous substrate via the so-called Ellman's method designed for identification of thiols (Ellman, 1959; Ellman et al., 1961). It is the most often used method in clinical biochemistry to include its employment in field individual equipment kits (Wilson, et al., 1997; Capacio et al., 2008). Its principle is splitting of hydrolysis-thiocholine (acetyl- or butyrylthiocholine) while releasing the appropriate acid and thiocholine according to the reaction scheme 8 . The thiocholine molecule contains the $\mathrm{SH}$ group which can be detected by means of the so-called Ellman's reagent, 5,5'-dithiobis(2nitrobenzoic) acid (DTNB). Splitting up the substrate into thiocholine is indicated by yellow coloring which is caused by development of a reduced form of the Ellman's reagent. This enables spectrophotometric detection at $412 \mathrm{~nm}$.

Various modifications of Ellman's reaction are used in a number of detection means such as detection tubes or a detection biosensor, Detehit (Tušarová \& Halámek, 2001). This means is utilized by the Armed Forces of the Czech Republic not only as an individual equipment item but also as a means of chemical survey and monitoring. It is a strip consisting of a zone with a cotton cloth with immobilized and stabilized acetylcholinesterase and a detection paper with acetylthiocholine iodide and 5,5'-dithiobis(2-nitrobenzoic) acid. The acetylcholinesterase is immobilized in the form of a stable enzyme chimera with polysaccharide cellulose. The enzyme remains the solid phase and its use is polyvalent. An advantage is the possibility of removing the surplus of organophosphate and reactivator by simply flushing the cloth with water.

This simple colorimetric biosensor can be used, after exposition through nucleophilic reagents, for selective inhibitor identification (Halámek et al., 2009; Hoskovcová et al., 2009). The nucleophilic reagents restore the function of the enzyme by unbinding the inhibitor from its active center under the formation of the so-called phosphorylated oxime. This exposition, however, must happen even before the development of the so-called nonreactivable form of the phosphorylated enzyme. In clinical practice compounds based on pyridinium aldoximes are used (Milatović \& Jokanović, 2009). Their efficacy varies and depends on many factors such as structure, number and placement of functional groups and cationic points, number of pyridinium nuclei etc., but also the type of the inhibitor. Thanks to those influences there is no broad-spectrum reactivator which would be able to react effectively with an enzyme inhibited by any nerve agent. Exactly the different efficacy of these oxime compounds compared to characteristic enzyme-inhibitor complexes results in the already mentioned change to the intensity of color of the biosensor. From the original white back to yellow owing to arising products of the substrate hydrolysis. The measurement of coloring intensity is done by detecting the reflectance of the color surface of an impregnated cloth (Tušarová et al., 1999; Hoskovcová et al., 2009).

For observing the activity of enzymes also other chromogens have been studied, e.g. indolephenylacetate, 2,6-dichlorindolephenyl acetate or $\beta$-naphthyl acetate, which are characteristic through blue coloring (Kramer \& Gamson, 1958; No et al., 2007), also 2-azobenzene-1-naphthylacetate with developing a red product (Epstein et al., 1957) or reaction with bromothymol blue which, due to $\mathrm{pH}$ changes in hydrolysis, switches from the originally blue-green color to the yellow one (Limperos \& Ranta, 1953). There has been also a description of substitution of the Ellman's reagent by a more stable compound 5-(2-aminoethyl)dithio-2-nitrobenzoate (Zhu et al., 2004).

Using the redox indicator of Guinea green B enables the indication of presence of the esterases inhibitor in automatic detectors. The basic principle is the ability of nerve agents to 
slow down or stop the biochemical reaction (see the reaction scheme 9). This reaction applies BuTCh and Guinea green B whereas the normal course of the enzyme-catalyzed hydrolysis will result in discoloring of indicator. In the presence of nerve agents there is no change to coloring (Český obranný standard, 2007).
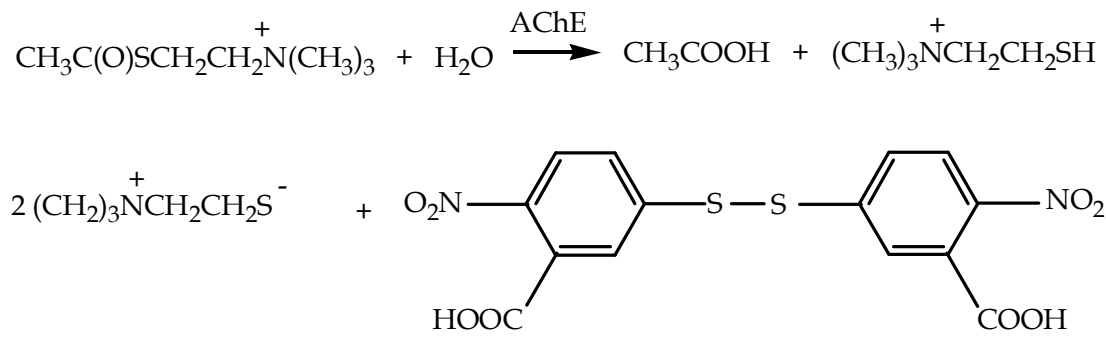

$\left(\mathrm{CH}_{3}\right)_{3} \stackrel{+}{\mathrm{N}} \mathrm{CH}_{2} \mathrm{CH}_{2}-\mathrm{S}-\mathrm{S}-\mathrm{CH}_{2} \mathrm{CH}_{2} \stackrel{+}{\mathrm{N}}\left(\mathrm{CH}_{3}\right)_{3}+$

2

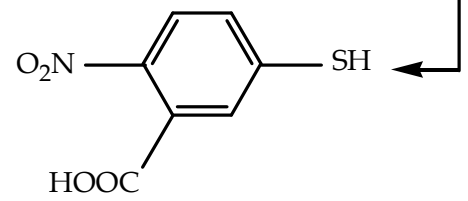

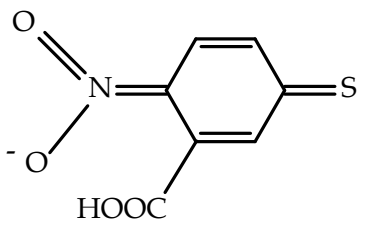

Reaction scheme 8. Ellman's method for identification of acetylthiocholine hydrolysis products.

For colorimetric evaluation a $\mathrm{pH}$ indicator strip has been developed, working in the range of pH 6.0 up to 7.7. The acetic acid originated from hydrolysis will be marked dark red in the detector. The method is comparable to the Ellman's method but in contrast to it there is an advantage of characteristic coloring which is visible even under the artificial light (Pohanka, et al. 2010a). Same as the previous means it can function without any other instrumentation and it offers a simple and rapid semiquantitative evaluation of contamination by cholinesterases inhibitors.

Another modification of the Ellman's method is a spectrophotometric FIA system developed for detection of pesticides in water. Here the acetylcholinesterase is immobilized on amidated glass pearls. The advantage of the system is the reactivation of an inhibited enzyme through 2-PAM reactivator (Dăneț, 2003). There has been also a procedure described where DTNB is substituted by a chemiluminescent substance - 1,2-dioxethane. 
The test is based on a chemically induced electron luminescent exchange (Sabelle et al., 2002).

The simple spectrophotometric identification has been described using a different chromogenous substrate, indophenyl acetate, which is hydrolyzed to a color product by enzymatic catalysis at $\mathrm{pH}$ 8. The production rate of this product depends on the enzyme activity (Kramer \& Gamson, 1958). There has been also a description of the method of spectrophotometric identification of pesticides in the analyte through measuring of color products of a-naphthol acetate. The substrate is catalytically hydrolyzed by AChE to anaphthol which reacts with $p$-nitrobenzendiazonium fluoroborate while developing color products (Leon-Gonzales \& Townshend, 1990).

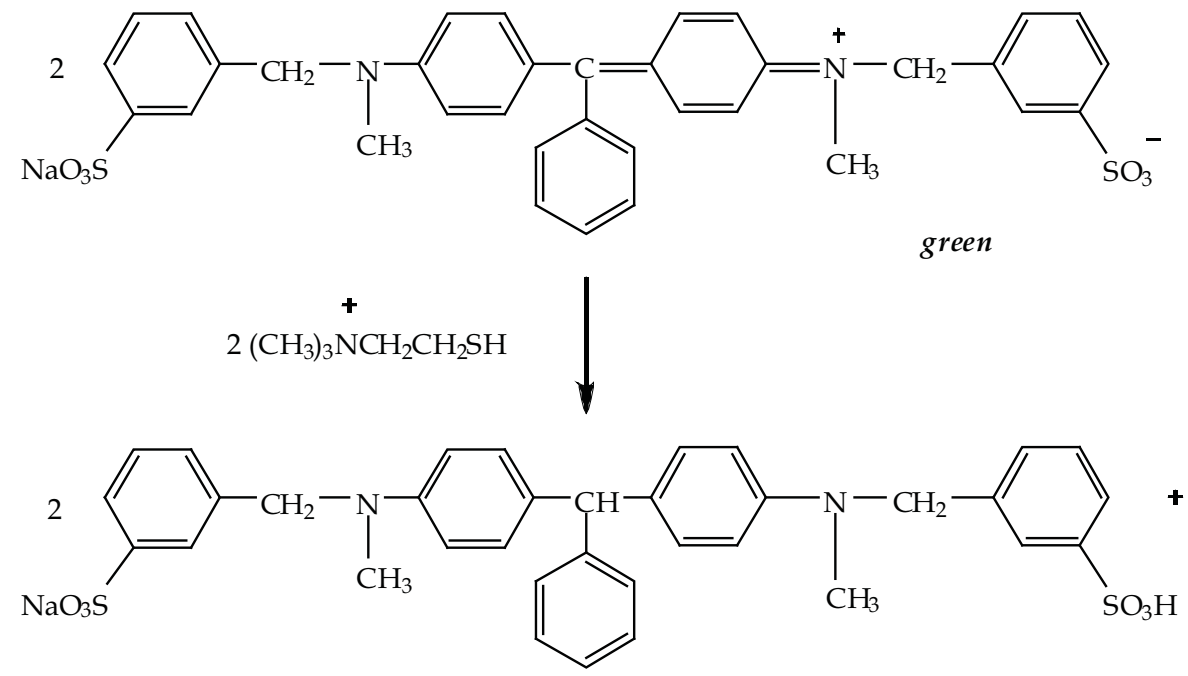

colourless

\section{$+\left(\mathrm{CH}_{3}\right)_{3} \mathrm{NCH}_{2} \mathrm{CH}_{2}-\mathrm{S}-\mathrm{S}-\mathrm{CH}_{2} \mathrm{CH}_{2} \mathrm{~N}\left(\mathrm{CH}_{3}\right)_{3}$}

Reaction scheme 9. Reaction mechanism of biochemical reaction modified by Guinea green B

Without the presence of chromogen the biosensors work based on non-linear optics. Conformation changes of the applied enzyme are measured, for example at adsorption of the produced thiocholine (Lin et al. 2006).

Also the system of spectrophotometric identification of cholinesterase inhibitors by means of an integrated acetyl-butyrylcholinesterase surface has been described. The interaction of these esterases with a reversible inhibitor, tetraphenyl porphyrin, leads to production of characteristic maxima at 446 and $421 \mathrm{~nm}$ in the absorption spectrum. The exposition through competitive inhibitors to a porphyrin-enzyme complex leads to reduction in values of absorbance intensity for both characteristic porphyrin-enzyme peaks, which is, however, not the case of noncompetitive inhibitors. The reduction of absorbance is caused by dissociation of porphyrin from active enzyme sites (Brandy et al., 2003).

It seems to be interesting to use the so-called chromo-fluorogenous reagents with gold nanoparticles. This nanotechnology was successfully tested for example for detection of 
paraoxon. The system consists of $\mathrm{AChE}, \mathrm{HAuCl}_{4}$, gold nanoparticles and acetylthiocholine iodide. The plasmon absorbance band of nanoparticles has higher intensity (blue) after increasing the concentration of aceylthiocholine. The gold nanoparticles enlarge with increasing the substrate concentration, which can be caused by increased production of thiocholine that acts as a reduction substance for $\mathrm{AuCl}_{4}$, while producing the metal gold which is deposited onto gold nanoparticles. These gold nanoparticles increase their size proportionally to the concentration of thiocholine whereby changes to plasmon absorbance are made. The gold nanoparticles are deposited onto a glass surface. In reaction of enzyme with substrate the blue coloring will be shown $(\lambda=570 \mathrm{~nm})$, after adding an inhibitor the plasmon band will be reduced and the glass plate will turn pink (Pavlov et al., 2005).

\subsubsection{Fluorescent biosensors}

This type of optical biosensors has been described especially in recent years. It is based on the principle of detecting fluorescent changes caused by the shift of $\mathrm{pH}$ in the course of substrate hydrolysis (Díaz \& Peinado, 1997).

Various papers describe a greater number of fluorescent substances which are suitable for detection of nerve agents as well as organophosphorus pesticides and their simulators (Dale \& Rebek, 2006; Bencic-Nagale et al., 2006) but many of them do not correspond to modification of the cholinesterase method; that is why they will not be included in this chapter. Probably the first fiber optic cholinesterase biosensor with a fluorescent substance was constructed with immobilized AChE with fluorescein isothiocyanate (FITC) on quartz fibers (FITC-AChE) (Rogers et al., 1991). In the course of ACh hydrolysis, depending on the $\mathrm{pH}$ change, a fluorescent signal under the influence of FITC-AChE is produced in the system. It is present in the evanescent zone of the fiber surface and is quenched by produced protons, which enables detecting the enzyme activity. Totally different is the fiber optic biosensor based on covalently bonded AChE on isothiocyanate glass mixed with thymol blue (immobilized on aminopropylic glass) and subsequently measuring the reflectance of color changes of a $\mathrm{pH}$-sensitive indicator in the course of enzyme-catalyzed hydrolysis at $600 \mathrm{~nm}$ (Andres \& Narayanaswamy, 1997).

Fiber-optic biosensors provide a lot of benefits such as the possibility of miniaturization, the possibility of remote sensing, in situ monitoring without the necessity of direct electric supply, and except for that they minimize undesirable interactions between the fluorescent detector and the sample.

The sol-gel technology meant a significant advancement for the construction of optical biosensors. Very often it is used just for the optical fluorescent biosensors. These biosensors contain a pH-sensitive fluorescent indicator encapsulated along with the enzyme in the solgel network. Biorecognition elements are protected by polymeric material which enables the substrate to diffuse easily to the enzyme and to be bonded subsequently. For detection of organophosphorus pesticides we have used for example the ChE immobilized in the sol-gel silicone matrix along with indoxyl-acetate substrate which is not a fluorescent substance but its hydrolysis gives rise to a highly fluorescent indoxyl. In the presence of the AChE inhibitor this fluorescence is reduced (Díaz \& Peinado, 1997). In the paper (Tsai \& Doong, 2000) altogether nine fluorescent substances were used for optimization of the fiber-optic biosensor on the sol-gel principle for detection of organophosphorus pesticides whereas the best results were achieved with FITC-dextran.

The Ellman's reagent was substituted by fluorescent substances such as fluorescein-5maleimide or methylcoumarin maleimide analoga (Parvari et al., as cited in Capacio et al., 
2008). Same as DTNB they react with thiocholine substrates. Coumarinylphenylmaleimide (CPM) forms with thiocholine a CPM-thiocholine product which is continually monitored by laser-induced fluorescence. After inhibitor exposition the fluorescent signal is reduced due to decreased concentration of thiocholine originated from the hydrolytic reaction catalyzed by $\mathrm{AChE}$, and it results in negative peak depending on the type of inhibition (Hadd et al., 1999).

Another fluorescent biosensor for detection of pesticides applies AChE and a pH-sensitive fluorescent indicator - pyranine, immobilized onto nanoliposoms. Reducing the fluorescent signal of the $\mathrm{pH}$ indicator is proportional to the concentration of pesticides tested. This biosensor was tested for detection of the total toxicity in samples of drinking water (Vamvakaki \& Chaniotakis, 2007; as cited in Miao et al., 2010).

Using the fluorescent substances for detection of cholinesterases inhibitors has found its way also to analytical kits. Such an analysis is quick and reliable and it enables the acquisition of results even in the field conditions (Technical Bulletin 296, 1996; Product information K 015-F1, 2004; Product information A 12217, 2009).

\subsection{Piezoelectric biosensors}

Besides the already mentioned methods we also use biosensors with piezoelectric converters for detection of organophosphates and carbamates. This type of converters can be used for biosensors with AChE immobilized onto the crystal face which serves as a frequency control element for the connection of oscillator. This device works based on the principle of changes to resonance frequency of the crystal. The frequency rises as a result of changes to oscillation, thickness or elasticity of the film applied on the crystal (O'Sullivan \& Guilbault, 1999), i.e. in case of piezoelectric biosensors the change of resonance frequency depends directly on the mass of molecules bonded to the sensitive surface (Skládal, 1995; Grate et al., 1993; as all cited in Skládal \& Macholán, 1997).

In the paper (Abad et al., 1998) 3-indolylacetate, which is transformed to indigo as a result of enzymatic reactions, was used as a substrate. This insoluble pigment is entrapped on the surface of the crystal, which results in frequency changes. The rate and extent of enzymatic reaction are proportional to those frequency changes related to thickness of the QCM (Quartz crystal microbalance) surface, caused by the product of enzymatic reaction.

Another piezoelectric biosensor works, instead of detecting the enzyme activity - i.e. a substrate transformation, based on the principle of measuring the AChE bond to a reversible inhibitor, benzoylecgonine-1,8-dioxaoctane, which is immobilized onto the layer of 11mercaptomonoundecanoic acid on the gold surface of the sensor. The AChE bond to the inhibitor is detected by a mass-sensitive QCM detector. In case of presence of the organophosphate in a sample the enzyme bond to an immobilized reversible inhibitor is reduced. The reduction in mass changes is proportional to the concentration of a free inhibitor in a sample. This biosensor can be practically applied for control and quick analysis of the presence of organophosphates in water streams (Halámek et al., 2005).

\section{Enzyme immobilization}

The most important step in preparation of a biosensor is immobilization and stabilization of enzyme on the working surface. It can be an electrode or just a cloth or paper (Tušarová \& Halámek, 2001). The enzyme immobilization determines the possibilities and construction of a biosensor. The selection of an appropriate way of immobilization is important to keep the 
catalytic activity of the enzyme and the mechanism for signal transmission. This process is given by interactions between the enzyme and the surface of the given material which serves as a carrier. The principal requirement is to keep the given system sufficiently stable and efficient and to preserve its sensitivity and selectivity. An unsubstitutable role is played also by the cost of the whole system.

Carrying matrices, which are used for enzyme immobilization, can be included in groups of natural polymers such as polysaccharides or proteins, synthetic polymers such as polystyrene, polyacrylates, methacrylates etc. or inorganic carriers such as minerals, active carbon, fiber glasses or porous metal oxides (Pohanka et al., 2010 b; Doretti et al., 1998).

The basic methods for enzyme immobilization include physical adsorption, covalent bond, self-assembled monolayer (SAM), physical entrapment and affinity precipitation (Andreescu \& Marty, 2006). The AChE immobilized for purposes of detection of organophosphorus substances, however, should not be entrapped by high affinity.

The physical adsorption of an enzyme onto the surface is supported by van der Waal's forces, thus the bond is very weak. This way of immobilization is the simplest one within the whole range of techniques used. It is characterized by disadvantages such as a weak operational stability and limited storing capacities.

The most often used way of immobilization is the covalent bond. This method commonly uses the modifications of converters with a bifunctional cross-linker such as glutaraldehyde, carbodiimide/succinimide or aminopropyltriethoxysilanes, albumin, chitosan etc., which are scaled on the supporting side activated by amino, carboxyl or hydroxyl groups and on the other side with biomolecules. This technique means increasing the stability of enzyme but the disadvantage is a great amount of bioreagent and lower reproducibility (Andreescu \& Marty, 2006; Gyurcsányi et al., 1999; Kandimalla \& Ju, 2006; Li et al., 1999; Nunes et al., 2004). The most often applied immobilization technique is the cross-linking by means of glutaraldehyde. The cross-linking of enzyme with glutaraldehyde on an electropolymeric polyethyleneimine film on the electrode surface was used for example for potentiometric measurement in the paper (Reybier et al., 2002). Polyethylenimine as a carrier for ChE was used also for a screen electrode in the paper (Montesinos et al., 2001), chitosan with MWNT (Kandimalla \& Ju, 2006) or with a glassy carbon electrode (Sun \& Wang, 2010); the bienzymatic AChE-ChO system is immobilized through glutaraldehyde to a glass electrode modified by Au-Pt nanoparticles (Upadhyay et al., 2009) etc.

The self-assembled monolayer exploits the placement of a thin layer directly onto the converter. The layer is made up of strong adsorption of alkenesilanes or disulfides, sulfides and thiols onto the metallic surface of the converter. Very often gold surfaces are used (Somerset et al., 2009). However, also other electrode materials are exploited, such as carbon nanotubes (Liu \& Lin, 2006). The stability of a layer is ensured through formation of long chains of $n$-alkylthiols or silanes. This immobilization technique enables the orientation and space control of the enzyme and degradation of diffusion barriers. A disadvantage is the repeated layering of biomolecules (Andreescu \& Marty, 2006, Arduini et al., 2010).

The mechanical entrapment is possible through a photopolymeric monomer, sol-gel matrix or nanoparticles and magnetic microparticles (Pohanka et al., 2009). The enzyme, transmitters and possible additives can be entrapped in one layer (Andreescu \& Marty, 2006). The entrapment in photopolymeric matrix includes mixing the enzyme with monomer with subsequent polymerization under the neon lamp (Andreescu et al., $2002 b, c)$. The photopolymeric matrix is a material suitable for the use with various enzymes and for various types of electrodes. The sol-gel procedure enables the entrapment of organic 
molecules in an inorganic material. Compared to other immobilization techniques it enables the anchorage of a great amount of enzyme, thermal and chemical stability, the possibility for selection of size and shape of pores for penetration of a substrate or inhibitors and its preparation is simple. The so-called microencapsulation in pores of the sol-gel matrix is not dependant on protein properties, significantly reduces neither the activity nor the affinity of biomolecules, because the enzyme is not covalently bonded to the matrix. Very often the solgel silicate matrices are used for construction of fluorescent fiber-optic biosensors (Díaz \& Peinado, 1997) or as a carrier for biosensors based on reactions of nanoparticles (Du et al., 2008). The sol-gel technology was described even based on non-silicate matrices, e.g. with aluminium oxide, titanium, vanadium peroxide, zirconium dioxide or zinc oxide (Daigle \& Leech, 1997; Elessi et al., 1997; Li et al., 1998; Meulenkamp, 1998; as all cited in Sinha et al., 2010; Sinha et al., 2010).

Affinity tags represent a modern trend in enzyme immobilizations. This technique is focused on oriented and site-specific immobilization of enzymes. One of the trends is the formation of a bioaffinity bond between supporting and functional groups of proteins. This can be achieved through affinity interactions of functional groups of the activated electrode surface (lectins, (strept)avidin, sugars and metal chelates) and affinity tags of ChE. ChEs contain a limited number of those groups which are placed far enough from active sites and they are suitable for formation of an affinity bond (Andeescu \& Marty, 2006). There was a description of an immobilization method based on an affinity bond through metal chelate (nitriloacetic acid in the complex with nickel ions) and a hexa-histidine bond with genetically modified AChE (Andreescu et al., 2001, Andreescu et al., 2002c). Another way of affinity interactions includes the bond between avidin and biotin which was used for enzyme multilayer membrane sets on the surface of a quartz plate and electrode. The enzyme is immobilized in turns onto individual layers. This set can be used for both monoand bienzymatic biosensor (Chen et al., 1998). The streptavidin-biotin was used for AChE immobilization onto a carbon nanotube (CNT) (Gao et al., 2009). As for lectins, the use of concanavalin A is described. In the paper (Ivanov et al., 2010) there was a test of a biosensor with position-specified immobilized AChE through albumin, glutaraldehyde and lectin concanavalin A on a hybrid polymer membrane in combination with MWCN; in the paper (Bucur et al., 2004) an affinity bond using concanavalin A and a screen electrode is applied.

The biosensor selectivity and sensitivity depend on the conditions of immobilization. Very often we discuss the rule saying "a lower enzyme activity or a thinner enzymatic membrane means higher sensitivity or a lower detection limit of the inhibitor identified". According to the study (Ivanov et al., 2000) a thinner film with quicker reaction will be produced thanks to direct enzyme immobilization onto the electrode surface; however, this does not mean increasing the sensitivity of biosensor. It is caused by relative saturation of the enzyme layer with a substrate or an inhibitor and it depends on diffusion of reactants to this membrane. Buffering properties of the membrane material may contribute to relative accumulation of products of the catalyzed hydrolysis. This compensates for the lower enzyme activity and causes increasing the response of biosensor. It is important that the accumulation intensifies the changes to enzyme activity thanks to the contact of enzyme with inhibitor. The abovesaid results in reduction of a detection limit and a relative sensitivity reduction compared to biosensors without diffusion limits or mass transfers to the membrane surface. The influence of diffusion factors can be affected also by pre-concentrating of the pesticide at a membrane. Then the identification of inhibitor depends on its hydrophobicity (Ivanov et al., 2000). 
Membranes placed onto the enzymatic layer reduce the relative saturation of this layer with substrate and thus they increase the linear extent of the identified substrate concentration. When applying the enzyme inhibitors, they do not provide any bigger advantage because the maximum inhibitor sensitivity requires substrate saturation of the membrane. One of the possibilities for membrane protection is the nafion layer placed between the working surface of the sensor and the enzymatic layer. This configuration means reducing the response of biosensor on one hand but on the other hand it provides higher stability of the carbon layer and greater stability of the thin layer of immobilized ChE and it does not reduce the biosensor sensitivity (Gogol et al., 2000).

The metal nanoparticles can be of great importance for increasing the stability and speed of the response of biosensors. The nanoparticles act as transmitters of an electron transfer from an enzyme molecule to an electrode. Very often gold nanoparticles are used because of their biocompatibility with enzymes (Marinov et al., 2010; Pavlov et al., 2005; Yin et al., 2009). They roughen the surface and subsequently increase interactions on the electrode (Shulga \& Kirchoff, 2007). Also other nanoparticles were used, Au-CdS, placed on a gold electrode with AChE (Zayats et al., 2003; as cited in Shulga \& Kirchoff, 2007). The use of nanoparticles also includes carbon, zircon and CdS particles (Ion et al., 2010; Liu et al., 2008).

\section{Conclusion}

Many substances with an anti-cholinergic effect can be, besides extensive industrial applications, used in the military or misused for terrorist purposes as it is shown by events from the recent past when in 1988 the nerve agents were used by Iraq against the Kurdish minority or in 1995 during the terrorist attack in Tokyo subway, conducted by the Aum Shinrikyo sect. Every year millions of tons of those substances/agents are produced for the needs of agriculture, medicine, industry and many other branches. They are quite toxic and for living organisms they mean a considerable risk even at very low concentrations. For these reasons the importance of early detection and analysis is growing. Many analytical methods (GC, MS, GC-MS, HPLC etc.) require a long preparation of samples such as homogenization, extraction, purification or derivatization. Some of these procedures may lead to sample devaluation. An alternative for those lengthy and laborious procedures is offered by biosensors. They meet the requirements for a rapid detection of nerve agents or organophosphorus pesticides for a quick adoption of protective measures to conceal, evacuate the inhabitants and conduct decontamination with checking its efficiency. The above requirements also include an easy handling and low cost. Their other indisputable benefits include a low sample volume, a partial protection of the immobilized enzyme against undesirable physical phenomena, a possibility for monitoring of kinetic and dissociation constants and the type of inhibition. Newly the biosensors are used for evaluation of new AChE reactivators (Pohanka et al., 2007).

\section{References}

Abad, J.M.; Pariente, F.; Hernández, L.; Abruña, H.D. \& Lorenzo, E. (1998). Determination of organophosphorus and carbamate pesticides using a piezoelectric biosensor. Analytical Chemistry, Vol. 70, No. 14, pp. 2848-2855. ISSN 0003-2700

Andreescu, S.; Magearu, V.; Lougarre, A.; Fournier, D. \& Marty, J.-L. (2001). Immobilization of enzyme on screen-printed sensors via an histidine tail. Application to the 
detection of pesticides using modified choinesterase. Analytical Letters, Vol. 34, No. 4, pp. 529-540, ISSN 0003-2719

Andreescu, S.; Noguer, T.; Magearu, V. \& Marty, J.-L. (2002a). Screen-printed electrode based on AChE for the detection of pesticides in presence of organic solvents. Talanta, Vol. 57, No. 1, pp. 169-176, ISSN 0039-9140

Andreescu, S.; Avramescu, A.; Bala, C.; Magearu, V. \& Marty, J.-L. (2002b). Detection of organophosphorus insecticides with immobilized acetylcholinesterase - Comparative study of two enzyme sensors. Analytical and Bioanalytical Chemistry, Vol. 374, No. 1, pp. 39-45, ISSN 1618-2642

Andreescu, S.; Barthelmebs, L. \& Marty, J.-L. (2002c). Immobilization of acetylcholinesterase on screen-printed electrodes: Comparative study between three immobilization methods and applications to the detection of organophosphorus insecticides. Analytica Chimica Acta, Vol. 464, No. 2, pp. 171-180, ISSN 0003-2670

Andreescu, S. \& Marty, J.-L. (2006). Twenty years research in cholinesterase biosensors: From basic research to practical applications. Review. Biomolecular Engineering, Vol. 23, pp. 1-15, ISSN 1389-0344

Andres, R.T. \& Narayanaswamy, R. (1997). Fibre-optic biosensor based on covalently immobilized acetylcholiesterase and tymol blue. Talanta, Vol. 44, No. 8, pp. 13351352, ISSN 0039-9140

Arduini, F.; Amine, A.; Moscone, D. Ricci, F. \& Palleschi, G. (2007). Fast, sensitive and costeffective detection of nerve agents in the gas phase using a portable instrument and an electrochemical biosensor, Analytical and Bioanalytical Chemistry, Vol. 388, No. 56, pp. 1049-1057, ISSN 1618-2642

Arduini, F.; Amine, A.; Moscone, D. \& Palleschi, G. (2010). Biosensors based on cholinesterase inhibition for insecticides nerve agents and aflatoxin $\mathrm{B}_{1}$ detection (review). Microchimica Acta, Vol. 170, No. 3-4, pp. 193-214, ISSN 0026-3672

Arkhypova, V.N.; Dzyadevych, S.V.; Soldatkin, A.P.; El'skaya, A.V.; Jaffrezic-Renault, N.; Jaffrezic, H. \& Martelet, C. (2001). Multibiosensor based on enzyme inhibition analysis for determination of different toxic substances. Talanta, Vol. 55, No. 5, pp. 919-927, ISSN 0039-9140

Bachmann, T.T. \& Schmidt, R.D. (1999). A disposable multielectrode biosensor for rapid simultaneous detection of the insecticides paraoxon and carbofuran at high resolution. Analytical Chimica Acta, Vol. 401, No. 1-2, pp. 95-103, ISSN 0003-2670

Bachmann, T.T.; Leca, B.; Vilatte, F.; Marty, J.-L.; Fournier, D. \& Schmid, R.D. (2000). Improved multianalyte detection of organophosphates and carbamates with disposable multielectrode biosensors using recombinant mutants of Drosophila acetylcholinesterase and artificial neural networks. Biosensors and Bioelectronics, Vol. 15, No. 3-4, pp. 193-201, ISSN 0956-5663

Bencic-Nagale, S.; Sternfeld, T. \& Walt, D.R. (2006). Microbead chemical switches: An approach to deection of reactive organohosphate chemical warfare agent vapors. Journal of American Chemical Society, Vol. 128, No. 15, pp. 5041-5048, ISSN 0002-7863

Bernabei, M.; Chiavarini, S.; Cremisini, C. \& Palleschi, G. (1993). Anticholinesterase activity measurement by a choline biosensor: Application in water analysis. Biosensors and Bioelectronics, Vol. 8, No. 5, pp. 265-271, ISSN 0956-5663 
Brandy, J.; White, B.J.; Legako, J.A. \& Harmon, H.J. (2003). Spectrophotometric detection of cholinesterase inhibitors with an integrated acetyl-/butyrylcholinesterase surface. Sensors and Actuators, B: Chemical, Vol. 89, No. 1-2, pp. 107-111, ISSN 0925-4005

Bucur, B.; Danet, A.F. \& Marty, J.-L. (2004). Versatile method of cholinesterase immobilisation via affinity bonds using Concanavalin A applied to the construction of a screen-printed biosensor. Biosensors and Bioelectronics, Vol. 20, No. 2, pp.217225, ISSN 0956-5663

Bucur, B.; Dondoi, M.; Danet, A. \& Marty J.L. (2005). Insecticide identification using a flow injection analysis systém with biosensors based on variol cholinesterases. Analytica Chimica Acta, Vol. 539, pp. 195-201, ISSN 0003-2670

Campanella, L.; Cocco, R., Sammartino, M.P. \& Tomassetti, M. (1992). A new enzyme inhibition sensor for organophosphorus pesticides analysis. The Science of the Total Environment, Vol. 123-124, pp. 1-16, ISSN 0048-9697

Campanella, L.; Lelo, D.; Martini, E. \& Tomassetti, M. (2007). Organophosphorus and carbamate pesticide analysis using an inhibition tyrosinase organic phase enzyme sensor; comparison by butyrylcholinesterase + choline oxidase opee and application to natural waters. Analytical Chimica Acta, Vol. 587. No. 1., pp. 22-32, ISSN 0003-2670

Capacio, B.R.; Smith, J.R.; Gordon, R.K.; Haigh, J.R.; Barr, J.R. \& Lukey, B.J. (2008). Clinical detection of exposure to chemical warfare agents, In: Chemical Warfare Agents: Chemistry, Pharmacology, Toxicology and Therapeutics, Romano, J.A., Lukey, B.J. \& Salem, H., pp. 501-548, Taylor \& Francis Group, ISBN-13: 978-1-4200-4661-8

Carmona, G.N.; Jufer, R.A.; Goldberg, S.R.; Gorelick, D.A.; Greig, N.H.; Yu, Q.S.; Cone, E.J. \& Schindler, C.W. (2000). Butyrylcholinesterase accelerates cocaine metabolism: in vitro and in vivo effects in nonhuman primates and humans. Drug Metabolism and Disposition, Vol. 28, No. 3, pp. 367-371, ISSN 0090-9556

Ciucu, A.A.; Negulescu, C. \& Baldwin R.P. (2003). Detection of pesticides using an amperometric biosensor based on ferophthalocyanine chemically modified carbon paste electrode and immobilized bienzymatic system. Biosensor and Bioelectronics, Vol. 18, pp. 303-310, ISSN 0956-5663

Český obranný standard. (2007). Základní metody vhodné pro detekci OL a PTL, In: Automatické signalizátory bojových otravných látek a průmyslových škodlivin, pp. 16-23. Úřad pro obrannou standardizaci, katalogizaci a státní ověřování jakosti, Praha. Czech Republic

Dale, T.J. \& Rebek, J. jr. (2006). Fluorescent sensor for organophosphorus nerve agent mimics. Journal of American Chemical Society, Vol. 128, No. 14, pp. 4500-4501, ISSN 0002-7863

Danzer, T. \& Schwedt, G. (1996) Development of biosensor system and evaluation of inhibition studies. Biosensors and Bioelectronics, Vol. 11, No. 8, pp. 18-19, ISSN 09565663

Dăneț, A.F.; Bucur, B.; Cheregi, M.-C.; Badea, M. \& Şerban, S. (2003). Spectrophotometric determination of organophosphoric insecticides in a FIA system based on AChE inhibition. Analytical Letters, Vol. 36, No. 1, pp. 59-73, ISSN 0003-2719

Ding, J. \& Qin, W. (2009). Polymeric membrane ion-selective electrode for butyrylcholinesterase based on controlled release of substrate. Electroanalysis, Vol. 21, No. 17-18, pp. 2030-2035, ISSN 1040-030003-271997 
Díaz, N.A.; Peinado, R.M.C. (1997). Sol-gel cholinesterase biosensor for organophosphorus pesticide fluorimetric analysis. Sensors and Actuators, B: Chemical, Vol. 38-39, No. 13, pp. 426-431, ISSN 0925-4005

Doretti, L.; Gattolin, P.; Burla, A.; Ferrara, D.; Lora, S. \& Palma, G. (1998). Covalently immobilized choline oxidase and cholinesterases on a methacrylate copolymer for disposable membrane biosensors. Applied Biochemistry and Biotechnology - Part A Enzyme Engineering and Biotechnology, Vol. 74, No. 1, pp. 1-12, ISSN 0273-2289

Du, D.; Huang, X.; Cai, J. \& Zhang. A. (2007). Comparison of pesticide sensitivity by electrochemical test based on acetylcholinesterase biosensor. Biosensors and Bioelectronics, Vol. 23, No. 2, pp. 285-289, ISSN 0956-5663

Du, D.; Chen, S.; Cai, J. \& Zhang, A. (2008). Electrochemical pesticide sensitivity test using acetylcholinesterase biosensor based on colloidal gold nanoparticle modified solgel interface. Talanta, Vol. 74, No. 4, pp. 766-772, ISSN 00399140

Dzyadevych, S.V.; Arkhypova, V.N.; Martelet, C.; Jaffrezic-Renault, N.; Chovelon, J.-M.; El'skaya, A.V. \& Soldatkin, A.P. (2004). Potentiometric biosensors based on ISFETs and immobilized cholinesterases. Electroanalysis, Vol. 16, No. 22, pp. 1873-1882, ISSN 1040-0397

Dzyadevych, S.V.; Arkhypova, V.N.; Martelet, C.; Jaffrezic-Renault, N.; Chovelon, J.-M.; El'skaya, A.V. \& Soldatkin, A.P. (2006). Potentiometric biosensors based on ISFETs and immobilised cholinesterases. International Journal of Applied Electromagnetics and Mechanics, Vol. 23, No. 3-4, pp. 229-244, ISSN 1383-5416

Dzyadevych, S.V.; Shulga, A.A.; Soldatkin, A.P.; Hendi, A.M.N.; Jaffrezic-Renault, N. \& Martelet, C. (2005). Conductometric biosensors based on cholinesterases for sensitive detection of pesticides. Electroanalysis, Vol. 6, pp. 752-758, ISSN 1040-0397

Ellman, G.L. (1959). Tissue sulfhydryl groups. Archives of Biochemistry and Biophysics, Vol. 82, pp. $70-77$

Ellman, G.L.; Courtney, K.D.; Andres, V. jr. \& Featherstone, R.M. (1961). A new and rapid colorimetric determination of acetylcholiesterase activity. Biochemical Pharmacology, Vol. 7, pp. 88-95, ISSN 0006-2952

Epstein, J.; Demek, M. \& Wolff, V.C. (1957). Enzymatic method for estimation of sarin in dilute aqueous solution. Analytical Chemistry, Vol. 29, No. 7, pp. 1050-1053, ISSN 0003-2700

Espinosa, M.; Atanasov, P. \& Wilkins, E. (1999). Development of a disposable organophosphate biosensor. Electroanalysis, Vol. 11, No. 14, pp. 1055-1062, ISSN 1040-0397

Evtugyn, G.A.; Rizaeva, E.P.; Stoikova, E.E.; Latipova, V.Z. \& Budnikov, H.C. (1997). The application of cholinesterase potentiometric biosensor for preliminary screening of the toxicity of waste waters Electroanalysis, Vol. 9, No. 14, pp. 1124-1128, ISSN 1040-0397

Chen, Q.; Kobayashi, Y.; Takeshita, H.; Hoshi, T. \& Anzai, J.-I. (1998). Avidin-biotin systembased enzyme multilayer membranes for biosensor applications: optimization of loading of choline esterase and choline oxidase in the bienzyme membrane for acetylcholine biosensors. Electroanalysis, Vol. 10, No. 2, pp. 94-97, ISSN 1040-0397

Ghindilis, A.L.; Morzunova, T.G.; Barmin, A.V. \& Kurochkin, I.N. (1996). Potentiometric biosensor for cholinesterase inhibitor analysis based on mediatorless 
bioelectrocatalysis. Biosensors and Biocatalysis, Vol. 11, No. 9, pp. 873-880, ISSN 09565663

Ghindilis, A.L.; Atanasov, P. \& Wilkins, E. (1997). Enzyme-catalyzed direct electron transfer: Fundamentals and analytical applications. Electroanalysis, Vol. 9, No. 9, pp. 661-674, ISSN 1040-0397

Gao, Y.; Kyratzis, I.; Taylor, R.; Huynh, C. \& Hickey, M. (2009). Immobilization of acetylcholinesterase onto carbon nanotubes utilizing streptavidin-biotin interaction for the construction of amperometric biosensors for pesticides. Analytical Letters, Vol. 42, No. 16, pp. 2711-2727, ISSN 0003-2719

Gogol, E.V.; Evtugyn, G.A.; Marty, J.-L.; Budnikov, H.C. \& Winter, V.G. (2000). Amperometric biosensors based on nafion coated screen-printed electrodes for the determination of cholinesterase inhibitors. Talanta, Vol, 53, No. 2, pp. 379-389, ISSN 0039-9140

Gulla, K.C.; Gouda, M.D.; Thakur, M.S. \& Karanth, N.G. (2002). Reactivation of immobilized acetyl cholinesterase in an amperometric biosensor for organophosphorus pesticide. Biochimica et Biophysica Acta, Vol. 1597, No. 1, pp. 133-139, ISSN 01674838

Gyurcsányi, R.E.; Vágföldi, Z.; Tóth, K. \& Nagy, G. (1999). Fast response potentiometric acetylcholine biosensor. Electroanalysis, Vol. 11, No. 10-11, pp. 712-718, ISSN 10400397

Hadd A.G.; Jacobson, S.C. \& Ramsey, M. (1999). Microfluidic assay of acetylcholinesterase inhibitors. Analytical Chemistry, Vol. 71, No. 22, pp. 5206-5212, ISSN 0003-2700

Halámek, J.; Přibyl, J.; Makower, P.; Skládal, P. \& Scheller, F.W. (2005). Sensitive detection of organophosphorus in river water by means of piezoelectric biosensor. Analytical and Bioanalytical Chemistry, Vol. 382, No. 8, pp. 1904-1911, ISSN 1618-2650

Halámek, E.; Kobliha, Z. \& Pitschmann, V. (2009). Organophosphorus chemical warfare agents, In: Analysis of chemical warfare agents, E. Halámek, Z. Kobliha \& V. Pitschmann, pp. 63-69, University of Defence, Institute of NBC Defence, ISBN 97880-7231-658-8, Brno, Czech Republic

Hanin, I. \& Dudas, B. (2000). Measurement of cholinesterase activity, In: Cholinesterases and Cholinesterase Inhibitors, Giacobini, E., pp. 139-144, Martin Dunitz, ISBN 1-85317910-8, U.K.

Hart, A.L.; Collier, W.A. \& Janssen D. (1997). The response of green-printed enzyme electrodes containing cholinesterases to organo-phosphates in solution and from commercial formulations. Biosensors and Bioelectronics, Vol. 12, No. 7, pp.645-654, ISSN 0956-5663

Hernandez, S.; Palchetti, I. \& Mascini, M. (2000). Determination of anticholinesterase activity for pesticide monitoring using a thiocholine sensor. International Journal of Envirnmental Analytical Chemistry, Vol. 58, No. 3-4, pp. 263-278, ISSN 0306-7319

Hestrin, S. (1949). The reaction of acetylcholine and other carboxylic acid derivatives with hydroxylamine, and its analytical application. Journal of Biological Chemistry, Vol. 180, No. 1, pp. 249-261, ISSN 0021-9258

Hildebrandt, A.; Bragós, R.; Lacorte, S. \& Marty, J.L. (2008). Performance of a portable biosensor for the analysis of organophosphorus and carbamate insecticides in water and food. Sensors and Actuators, B: Chemical, Vol. 133, No. 1, pp. 195-201, ISSN 09254005 
Holmstedt, B. (2000). Cholinesterase inhibitors: an introduction, In: Cholinesterases and Cholinesterase Inhibitors, Giacobini, E., pp. 1-8, Martin Dunitz, ISBN 1-85317-910-8, U.K.

Hoskovcová, M.; Kasalová, I.; Halámek, E. \& Kobliha, Z. (2009). Suggestion for selective differentiating of nerve agents $G$ and $V$ type with utilization of modified Ellman's method. Enviromental Chemistry Letters, Vol. 7, No. 3, pp. 277-281, ISSN 1610-3653

Imato, T. \& Ishibashi, N. (1995). Potentiometric butyrylcholine sensor for organophosphate pesticides. Biosensors and Bioelectronics, Vol. 10, No. 5, pp. 435441, ISSN 0956-5663

Ion, A.C.; Ion, I.; Culetu, A.; Gherase, D.; Moldovan, C.A.; Iosub, R. \& Dinescu, A. (2010). Acetylcholinesterase voltammetric biosensors based on carbon nanostructurechitosan composite material for organophosphate pesticides. Materials Science and Engineering C, Vol. 30, No. 6, pp. 817-821, ISSN 0928-4931

Istamboulie, G., Cortina-Puig, M., Marty, J.-L., Noguer, T. (2009). The use of Artificial Neural Networks for the selective detection of two organophosphate insecticides: Chlorpyrifos and chlorfenvinfos. Talanta, Vol. 79, No. 2, pp. 507-511, ISSN 00399140

Ivanov, A.; Evtugyn, G.; Gyurcsányi, R.E.; Tóth, K. \& Budnikov, H.C. (2000). Comparative investigation of electrochemical cholinesterase biosensors for pesticide determination. Analytica Chimica Acta, Vol. 404, No. 1, pp. 55-65, ISSN 0003-2670

Ivanov, A.; Evtugyn, G.; Budnikov, H.; Ricci, F.; Moscone, D. \& Palleschi, G. (2003a). Cholinesterase sensors based on screen-printed electrodes for detection of organophosphorus and carbamic pesticides. Analytical and Bioanalytical Chemistry, Vol. 377, No. 4, pp. 624-631, ISSN 1618-2642

Ivanov, A.N.; Evtugyn, G.A.; Lukachova, L.V.; Karyakina, E.E.; Budnkov H.C.; Kiseleva, S.G.; Orlov A.V.; Karpacheva, G.P. \& Karyakin A.A. (2003b). New polyaniline based potemtiometric biosenzor for pesticides detection. IEEE Sensors Journals Analycal Chemistry Department, Vol. 3, No. 3, pp. 333-340, ISSN 1530-437X

Ivanov, Y.; Marinov, I.; Gabrovska, K.; Dimcheva, N. \& Godjevargova, T. (2010). Amperometric biosensor based on a site-specific immobilization of acetylcholinesterase via affinity bonds on a nanostructured polymer membrane with integrated multiwall carbon nanotubes. Journal of Molecular Catalysis B: Enzymatic, Vol. 63, No. 3-4, pp. 141-148, ISSN 1381-1177

Joshi, K.A.; Prouza, M.; Kum, M.; Wang, J.; Tang, J.; Haddon, R.; Chen, W. \& Mulchandani, A. (2006). V-type nerve agent detection using a carbon nanotube-based amperometric enzyme electrode. Analytical Chemistry, Vol. 78, No. 1, pp. 331-336, ISSN 0003-2700

Kandimalla, V.B. \& Ju, H. (2006). Binding of acetylcholinesterase to multiwall carbon nanotube-cross-linked chitosan composite for flow-injection amperometric detection of an organophosphorus insecticide. Chemistry - A European Journal, Vol. 12, pp. 1074-1080, ISSN 1521-3765

Karnati, C.; Du, H.; Ji, H.F.; Xu, X.; Lvov, Y.; Mulchandani, A.; Mulchandani P. \& Chen W. (2007). Organophosphorus hydrolase multilayer modified microcantilevers for organophosphorus detection. Biosensors and Bioelectronics, Vol. 22, pp. 2636-2642, ISSN 0956-5663 
Karyakin, A.A.; Bobrova, O.A.; Lukachova, L.V. \& Karyakina, E.E. (1996). Potentiometric biosensors based on polyaniline semiconductor films. Sensors and Actuators, B: Chemical, Vol. 33, No. 1-3, pp. 34-38, ISSN 0925-4005

Kenar, L. (2010). The use of biosensors for the detection of chemical and Biological Weapons. Turkish Journal of Biochemistry, Vol. 35, No. 1, pp. 72-74. ISSN 0250-4685

Kok, F.N. \& Hasirci, V. (2004). Determination of binary pesticide mixtures by an acetylcholinesterase- choline oxidase biosensor. Biosensors and Bioelectronics, Vol. 19, No. 7, pp. 661-665, ISSN 0956-5663

Koncki, R. \& Mascini, M. (1997). Screen-printed ruthenium dioxide electrodes for $\mathrm{pH}$ measuremnts. Analytica Chimica Acta, Vol. 351, No. 1-3, pp. 143-149, ISSN 00032670

Kramer, D.N. \& Gamson R.M. (1958). Colorimetric determination of acetylcholinesterase activity. Analytical Chemistry, Vol. 30, No. 2, pp.251-254, ISSN 0003-2700

Kua, J.; Zhang, Y. \& McCammon, A. (2002). Studying enzyme binding specifity in acetylcholinesterase using a combined molecular dynamics and multiple docking approach. Journal of American Chemical Society, Vol. 124, No. 28, pp. 8260-8267, ISSN 0002-7863

La Rosa, C.; Pariente, F.; Hernández, L. \& Lorenzo, E. (1994). Determination of organophosphorus and carbamic pesticides with an acetylcholinesterase amperometric biosensor using 4-aminophenyl acetate as substrate. Analytica Chimica Acta, Vol. 295, No. 3, pp. 273-282, ISSN 0003-2670

Lee, H.-S.; Kim, A.Y.; Cho, A.Y. \& Lee, T.Y. (2002). Oxidation of organophosphorus pesticides for the sensitive detection by a cholinesterase-based biosensor. Chemosphere, Vol. 46, No. 4, pp. 571-576, ISSN 0045-6535

Leon-Gonzales, M.E. \& Townshend, A. (1990). Flow-injection determination of paraoxon by inhibition of immobilized acetylcholinesterase. Analytica Chimica Acta, Vol. 236, pp. 267-272, ISSN 0003-2670

Li, Y.-G.; Zhou, Y.-X.; Feng, J.-L.; Jiang, Z.-H. \& Ma, L.-R. (1999). Immobilization of enzyme on screen-printed electrode by exposure to glutaraldehyde vapour for the construction of amperometric acetylcholinesterase electrodes. Analytica Chimica Acta, Vol. 382, No. 3, pp. 277-282, ISSN 003-2670

Limperos, G. \& Ranta, K.E. (1953). A rapid screening test for the determination of the approximate cholinesterase activity of human blood. Science, Vol. 117, No 3043, pp. 453-455, ISSN 0036-8075

Lin, T.J.; Huang, K.T. \& Liu, C.Y. (2006). Determination of organophosphorus pesticides by a novel biosensor based on localized surface plasmon resonance. Biosensors and Bioelectronics, Vol. 22, No. 4, pp. 513-518, ISSN 0956-5663

Lin, Y., Lu, F., Wang, J. (2004). Disposable carbon nanotube modified screen-printed biosensor for amperometric detection of organophosphorus pesticides and nerve agents. Electroanalysis, Vol. 16, No. 1-2, pp. 145-149, ISSN 1040-0397

Liu, G.; Richers, S.L.; Mellen, M.C. \& Lin, Y. (2005). Sensitive electrochemical detection of enzymatically generated thiocholine at carbon nanotube modified glasssy carbon electrode. Electrochemistry Communications, Vol. 7, No. 11, pp. 1163-1169, ISSN 13882481

Liu, G. \& Lin Y. (2006). Biosensor based on self-assembling acetylcholinesterase on carbon nanotubes for flow injection/amperometric detection of organophosphate 
pesticides and nerve agents. Analytical Chemistry, Vol. 78, No. 3, pp. 835-843, ISSN 0003-2700

Liu, G.; Wang, J.; Barry, R.; Petersen, C.; Timchalk, C.; Gassman, P.L. \& Lin, Y. (2008). Nanoparticle-based electrochemical immunosensor for the detection of phosphorylated acetylcholinesterase: An exposure biomarker of organophosphate pesticides and nerve agents. Chemistry - A European Journal, Vol. 14, No. 32, pp. 9951-9959, ISSN 1521-3765

Makower, A.; Halámek, J.; Skládal, P.; Kernchen, F. \& Scheller, F.W. (2003). New principle of direct real-time monitoring of the interaction of cholinesterase and its inhibitors by piezoelectric biosensor. Biosensors and Bioelectronics, Vol. 18, No. 11, pp. 1329-1337, ISSN 0956-5663

Marinov, I.; Ivanov, Y.; Gabrovska, K. \& Godjevargova, T. (2010). Amperometric acetylthiocholine sensor based on acetylcholinesterase immobilized on nanostructured polymer membrane containing gold nanoparticles. Journal of Molecular Catalysis B: Enzymatic, Vol. 62, No. 1, pp. 66-74, ISSN 1381-1177

Martorell, D.; Céspedes, F.; Martínez-Fàbregas, E. \& Alegret, S. (1994). Amperometric determination of pesticides using a biosenzor based on a polishable graphiteepoxy biocomposite. Analytica Chimica Acta, Vol. 290, No. 3, pp. 343-348, ISSN 0003-2670

Marty J.-L.; Mionetto, N.; Noguer, T.; Ortega F. \& Roux C. (1993). Enzyme sensors for the detection of pesticides. Biosensors and Bioelectronics, Vol. 8, No. 6, pp. 273-280, ISSN 0956-5663

Masson, P.; Carletti, E. \& Nachon, F. (2009). Structure, activities and biomedical applications of human butyrylcholinesterase. Protein and Peptide Letters, Vol. 16. No. 10, pp. 1215-1224, ISSN 0929-8665

Miao, Y.; He, N. \& Zhu, J.-J. (2010). History and new developments of assays for cholinesterase activity and inhibition. Chemical Reviews, Vol. 110, No. 9, pp. 52165234, ISSN 0009-2665

Milatović, D. \& Jokanović, M. (2009). Pyridinium oximes as cholinesterase reactivators in the treatment of OP poisoning, In: Hadbook of Toxicology of Chemical Warfare Agents, Gupta, R.C., pp. 985-996, Elsevier, ISBN 978-0-12-374484-5, U.K.

Mitchell, K.M. (2004). Acetylcholine and choline amperometric enzyme sensors characterized in vitro and in vivo. Analytical Chemistry, Vol. 76, No. 4, pp. 10981106, ISSN 0003-2700

Mizutani, F. \& Tsuda, K. (1982). Amperometric determination of cholinesterase with use of an immobilized enzyme electrode. Analytica Chimica Acta, Vol. 139, No. 1, pp. 356362, ISSN 0003-2670

Montesinos, T.; Peréz-Munguia, S.; Valdez, F. \& Marty, J.-L. (2001). Disposable cholinesterase biosensor for the detection of pesticides in water-miscible organic solvents. Analytica Chimica Acta, Vol. 431, No. 2, pp. 231-237, ISSN 00032670

Mulchandani, A.; Mulchandani P. \& Chen, W. (1999a). Amperometric thick-film strip electrodes for monitoring organophosphate nerve agents based on immobilized organophosphorus hydrolase. Analytical Chemistry, Vol. 71, No. 11, pp. 2246-2249, ISSN 0003-2700 
Mulchandani, A.; Mulchandani, P.; Kaneva, I. \& Chen, W. (1999b). Biosensor for direct determination of organophosphate nerve agents. 1. Potentiometric enzyme electrode. Biosensors and Bioelectronics, Vol. 14, No. 1, pp. 77-85, ISSN 0956-5663

Mulchandani, A.; Chen, W.; Mulchandani, P.; Wang, J. \& Rogers, K.R. (2001). Biosensors for direct determination of organophosphate pesticides. Review. Biosensor and Bioelectronics, Vol. 16, No. 4-5, pp. 225-230, ISSN 0956-5663

No, H.-Y; Kim, Y.A.; Lee, Y.T. \& Lee, H.-S. (2007). Cholinesterase-based dipstick assai for the detection of organophosphate and carbamate pesticides. Analytica Chimica Acta, Vol. 594, No. 1., pp. 37-43, ISSN 0003-2670

Nunes, G.S.; Jeanty, G. \& Marty J.-L. (2004). Enzyme immobilization procedures on screenprinted electrodes used for the detection of anticholinesterase pesticides. Comparative study. Analytica Chimica Acta, Vol. 523, No. 1, pp. 107-115, ISSN 00032670

Oh, I. \& Masel, R.I. (2007). Electrochemical organophosphate sensor based on oxime chemismy. Electrochemical and Solid-State Letters, Vol. 10, No. 2, pp. J19-J22, ISBN 1099-0062

O’Sullivan, C.K. \& Guilbault, G.G. (1999). Commercial quartz crystal microbalances - theory and applications. Biosensors and Bioelectronics, Vol. 14, No. 8-9, pp. 663-670, ISSN 0956-5663

Palchetti, I.; Cagnini, A.; Del Carlo, M.; Coppi, C.; Mascini, M. \& Turner, A.P.F. (1997). Determination of anticholinesterase pesticides in real samples using a disposable biosensor. Analytica Chimica Acta, Vol. 337, No. 3, pp. 315-321, ISBN 0003-2670

Palleschi, G.; Bernabei, M.; Cremisini, C. \& Mascini, M. (1992). Determination of organophosphorus insecticides with a choline electrochemical biosensor. Sensors and Actuators: B. Chemical, Vol. 7, No. 1-3, pp. 513-517, ISSN 0925-4005

Pariente, F.; Hernández L. \& Lorenzo, E. (1993). 4-aminophenyl acetate as a substrate for amperometric esterase sensors. Analytica Chimica Acta, Vol. 273, No. 1-2, pp. 399407, ISSN 0003-2670

Pavlov, V.; Xiao, Y. \& Willner, I. (2005). Inhibition of the acetylcholine esterase-stimulated growth of $\mathrm{Au}$ nanoparticles: Nanotechnology-based sensing of nerve gases. Nano Letters, Vol. 5, No. 4, pp. 649-653, ISSN 1530-6984

Philips, J.W. (2005). Acetylcholine repase fro central nervous system: A 50-year retrospective. Critical Review in Neurobiology, Vol. 17. No. 3-4, pp. 161-217, ISSN 0892-0915

Pitschmann, V. (1999). Mezi světovými válkami. In: Historie chemické války. ed. V. Pitschman, pp. 41-45, Military System Line, s.r.o. ISBN 80-902669-0-8, Praha, Czech Republic

Pohanka, M.; Jun, D. \& Kuca, K. (2007). Amperometric biosensor for evaluation of competitive cholinesterase inhibition by the reactivator HI-6. Analytical Letters, Vol. 40, No. 12 , pp. 2351-2359, ISSN 0003-2719

Pohanka, M.; Kuča, K. \& Jun, D. (2008) Aflatoxin assay using an amperometric sensor strip and acetylcholinesterase as recognition element. Sensor Letters, Vol. 6, No. 3, pp. 450-453, ISSN 1546-198X

Pohanka, M. (2009). Cholinesterase based amperometric biosensors for assay of anticholinergic compounds. Interdisciplinary Toxicology, Vol. 2, No. 2, pp. 52-54, ISSN 1337-6853 
Pohanka, M.; Musílek, K. \& Kuča, K. (2009). Progress of biosensors based on cholinesterase inhibition. Current Medicinal Chemistry, Vol. 16, No. 14. Pp. 1790-1798, ISSN 09298673

Pohanka, M.; Karasová-Žd’árová, J.; Kuča, K.; Pikula, J.; Holas, O.; Korábečný, J. \& Cabal, J. (2010a). Colorimetric dipstick for assay of organophosphate pesticides and nerve agents represented by paraoxon, sarin and VX, Talanta, Vol. 81, No. 1-2, pp.621624, ISSN 0039-9140

Pohanka, M.; Vlček, V.; Žd'árová-Karasová, J.; Kuča, K. \& Cabal, J. (2010b). Colorimetric detectors based on acetylcholinesterase and its construction. Vojenské Zdravotnické listy, Vol. 79, No. 1, pp. 9-14, ISSN 0372-7025

Product information A 12217 (2004). Amplex ${ }^{\circledR}$ Red Acetylcholine/Acetylcholinesterase Assay Kit. Molecular Probes, Inc., USA, http://probes.invitrogen.com/media/pis/mp12217.pdf

Product information K015-F1 (2009). DetectX ${ }^{\circledR}$ Acetylcholinesterase Fluorescent Activity Kit. ArborAssay, USA, http://www.arborassays.com/products/inserts/K015-F1.pdf

Rekha, K.; Thakur M.S. \& Karanth N.G. (2000). Biosensors for the detection of organophosphorus pesticides. Critical Review in Biotechnology, Vol. 23, No. 3, pp. 213-235, ISSN 0738-8551

Reybier, K.; Zairi, S.; Jaffrezic-Renault, N. \& Fahys, B. (2002). The use of polyethyleneimine for fabrication of potentiometric cholinesterase biosensors. Talanta, Vol. 56, No. 6, pp. 1015-1020, ISSN 0039-9140

Ricci, F.; Amine, A.; Palleschi, G. \& Moscone, D. (2003). Prussian blue based greenprinted biosensors with improvedcharacteristics of long-term lefetime and $\mathrm{pH}$ stability. Biosensors and Bioelectronics, Vol. 18, No. 2-3, pp. 165-174, ISSN 09565663

Rogers, K.R.; Cao, C.J.; Valdes, J.J.; Eldefrawi, A.T. \& Eldefrawi, M.E. (1991). Acetylcholinesterase fiber-optic biosensor for detection of anticholinesterases. Fundamental and Applied Toxicology, Vol. 16, No. 4, pp. 810-820, ISSN 0272-0590

Rogers, K.R.; Wang, Y.; Mulchandani, A.; Mulchandani, P. \& Chen, W. (1999). Organophosphorus hydrolase-based assay for organophosphate pesticides. Biotechnology Progress, Vol. 15, No. 3, pp. 517-521, ISSN 8756-7938

Sabelle, S.; Renard, P.Y.; Pecorella, K.; De Suzzoni-dézard S.; Créminon, C.; Grassi, J. \& Mioskowski, C. (2002). Journal ofiAmerican Chemical Society, Vol. 124, No. 17, pp. 4874-4880, ISSN 0002-7863

Shulga, O. \& Kirchhoff, J.R. (2007). An acetylcholinesterase enzyme electrode stabilized by an electrodeposited gold nanoparticle layer. Electrochemistry Communications, Vol. 9, No. 5, pp. 935-940, ISSN 1388-2481

Simonian, A.L.; Grimsley, J.K.; Flounders, A.W.; Schoeniger, J.S.; Cheng, T.-C.; DeFrank, J.J. \& Wild, J.R. (2001). Enzyme-based biosensor for the direct detection of fluorinecontaining organophosphates. Analytica Chimica Acta, Vol. 442, No. 1, pp.15-23, ISSN 0003-2670

Sinha, R., Ganesana, M., Andreescu, S., Stanciu, L. (2010). AChE biosensor based on zinc oxide sol-gel for the detection of pesticides. Analytica Chimica Acta, Vol. 661, No. 2, pp. 195-199, ISSN 0003-2670 
Skládal, P.; (1992). Detection of organophosphate and carbamate pesticides using disposable biosensors based on chemically modified electrodes and immobilized cholinesterase. Analytica Chimica Acta, Vol. 269, pp. 281-287, ISSN 0003-2670

Skládal, P. \& Mascini, M. (1992). Sensitive detection of pesticides using amperometric sensors based on cobalt phtalocyanine-modified composite electrodes and immobilized cholinesterases. Biosensors and Bioelectronics, Vol. 7, No. 5, pp. 335-343, ISSN 0956-5663

Skládal, P. \& Macholán, L. (1997). Biosensory - současný stav a perspektivy. Chemické Listy, Vol. 91, pp. 105-113, ISSN 0009-2770

Snejdarkova, M.; Svobodova, L.; Evtugyn, G.; Budnikov, H.; Karyakin, A.; Nikolesis, D.P. \& Hianik, T. (2004). Acetylcholinesterase sensors based on gold electrodes modified with dendrimer and polyaniline. A comparative research. Analytica Chimica Acta, Vol. 514, No. 1, pp. 79-88, ISSN 003-2670

Somani S.M.; Solana, R.P. \& Dube, S.N. (1992). Toxicodinamics of nerve agents, In: Chemical Warfare Agents, Somani S.M., pp. 67-123, Academic Press, Inc., ISBN 0-12-654620-7, USA

Somerset, S.; Baker, P. \& Iwuoha, E.I. (2009). Mercaptobenzothiazole on-gold organic phase biosensors systems: 1 . Enhanced organophosphate pesticide determination. Journal of Environmental Science and Health Part B, Vol. 44, No. 2, pp. 164-178, ISSN 03601234

Sun, X. \& Wang, X. (2010). Acetylcholinesterase biosensor based on prussian blue-modified electrode for detecting organophosphorous pesticides. Biosensors and Bioelectronics, Vol. 25, No. 12, pp. 2611-2614, ISSN 0956-5663

Sun, X., Wang, X., Zhao, W. (2010). Multiwall carbon nanotube-based acetylcholinesterase biosensor for detecting organophosphorous pesticides, Sensor Letters, Vol. 8, No. 2, pp. 247-252, ISSN 1546-198X

Suprun, E.; Evtugyn, G.; Budnikov, H.; Ricci, F.; Moscone, D. \& Palleschi, G. (2005). Acetylcholinesterase sensor based on screen-printed carbon electrode modified with prussian blue. Analytical and Bioanalytical Chemistry, Vol. 383, No. 4, pp. 597604, ISSN 1618-2642

Sussman, J.L.; Harel, M.; Frolow, F.; Oefner, C.; Goldman, D.; Toker, L. \& Silman, I. (1991). Atomic structure of acetylcholinesterase from Torpedo californica: A prototypic acetylcholine binding protein. Science, Vol. 253, No. 5022, pp. 872-879, ISSN 00368075

Technical Bulletin 296. (1996). Verification of nerve agent exposure-monitoring blood cholinesterase activity with the tTest-Mate TM OP Kit, In: Assay techniques for detection of exposure to sutur mustard, cholinesterase inhibitors, sarin, soman, GF, and cyanide. pp. 3-1 - 3-3, Headquarters Department of the Army, Washington, DC, USA http://armypubs.army.mil/med/dr_pubs/dr_a/pdf/tbmed296.pdf

Teksoy, S.; Odaci, D. \& Timur, S. (2007). A new bienzymatic biosensor based on butyrylcholine esterase-sulfhydryl oxidase enzymes. Analytical Letters, Vol. 40, No. 15, pp. 2840-2850, ISSN 0003-2719

Tomeček, I. \& Matoušek, J. (1961). Organické fosforové otravné látky, In: Analýza bojových otravných látek, Tomeček, I. \& Matoušek, J., pp. 103-135, SPN Praha, Czech Republic 
Tran-Minh, C.; Pandey, P.C. \& Kumaran, S. (1990). Studies on acetylcholine sensor and its analytical application based on the inhibition of cholinesterase. Biosensors and Bioelectronics, Vol. 5, No. 6, pp. 461-471, ISSN0956-5663

Tsai, H.-C. \& Doong, R.-A. (2000). Optimization of sol-gel based fibre-optic cholinesterase biosensor for the determination of organophosphorus pesticides. Water Science and Technology, Vol. 42, No. 7-8, pp. 283-290, ISSN 0273-1223

Turdean, G.L.; Popescu, I.C.; Oniciu, L. \& Thevenot, D.R. (2002). Sensitive detection of organophosphorus pesticides using a needle type amperometric acetylcholinesterase based bioelectrode. Thiocholine electrochemistry and immobilized enzyme inhibition. Journal of Enzyme Inhibition and Medicinal Chemistry, Vol. 17, No. 2, pp. 107-115, ISSN 1475-6366

Tušarová, I.; Halámek, E. \& Kobliha, Z. (1999). Study on reactivation of enzyme-inhibitor complexes by oximes using acetylcholine esterase inhibited by organophosphate chemical warfare agents. Enzyme and Microbial Technology, Vol. 25, No. 3-5, pp. 400403, ISSN 0141-0229

Tušarová, I. \& Halámek, E. (2001). Biosenzor pro detekci a rozlišení inhibitorů cholinesteráz, způsob přípravy zóny biosenzoru s imobilizovanou cholinesterázou, způsob detekce inhibitorů cholinesteráz a zpo̊sob rozlišení inhibitorů cholinesteráz. Patent of the Czech Republic, ČR 288 576. 22.5.2001

Upadhyay, S.; Rao, G.R.; Sharma, M.K.; Bhattacharya, B.K.; Rao, V.K. \& Vijayaraghavan, R. (2009). Immobilization of acetylcholineesterase-choline oxidase on a gold-platinum bimetallic nanoparticles modified glassy carbon electrode for the sensitive detection of organophosphate pesticides, carbamates and nerve agents. Biosensors and Bioelectronics, Vol. 25, No. 4, pp. 832-838, ISSN 0956-5663

Wang, J.; Chen, L.; Mulchandani, A.; Mulchandani, P. \& Chen, W. (1999). Remote biosensor for in-situ monitoring of organophosphate nerve agents. Electroanalysis, Vol. 11, No. 12, pp. 866-869, ISSN 1040-0397

Wang, J.; Krause, R.; Block, K.; Musameh, M.; Mulchandani, A. \& Schöning, M.J. (2003). Flow injection amperometric detection of OP nerve agents based on an organophosphorus-hydrolase biosensor detector. Biosensors and Bioelectronics, Vol. 18, No. 2-3, pp. 255-260, ISSN 0956-5663

Watson, A.; Opresko, D.; Young, R.; Hauschild; V.; King, J. \& Bakshi, K. (2009). Organophosphorus Nerve agents, In: Hadbook of Toxicology of Chemical Warfare Agents, Gupta, R.C., pp. 43-67, Elsevier, ISBN 978-0-12-374484-5, U.K.

Wilson, B.W.; Sanborn, J.R.; O’Malley, M.A.; Henderson, J.D. \& Billitti, J.R. (1997). Monitoring the pesticide-exposed worker. Occupational Medicine, Vol. 12, No. 2, pp. 347-363, ISSN 0885-114X

Wring, S.A.; Hart, J.P. \& Birch, B.J. (1989). Development of an improved carbon electrode chemically modified with cobalt phtalocyanine as a reusable sensor for glutathione. Analyst, Vol. 116, pp. 1563-1570, ISSN 0003-2654

Yao, T. (1983) Flow injection analysis for cholinesterase in blood serum by use of a cholinesensitive electrode as an amperometric detector. Analytica Chimica Acta, Vol. 153, No. 1, pp. 169-174, ISSN 0003-2670

Yin, H.; Ai, S.; Xu, J.; Shi, W. \& Zhu, L. (2009). Amperometric biosensor based on immobilized acetylcholinesterase on gold nanoparticles and silk fibroin modified 
platinum electrode for detection of methyl paraoxon, carbofuran and phoxim. Journal of Electroanalytical Chemistry, Vol. 637, No. 1-2, pp. 21-27, ISSN 0022-0728

Zhang, J.; Luo, A; Liu, P.; Wei, S.; Wang, G. \& Wei, S. (2009). Detection of organophosphorus pesticides using potentiometric enzymatic membrane biosensor based on methylcellulose immobilization. Analytical Sciences, Vol. 25, No. 4, pp. 511-515, ISSN 0910-6340

Zhu, J.; Dhimitruka, I. \& Pei, D. (2004). 5-(2-amino)dithio-2-nitrobenzoate as a more basestable alternative to Ellman's reagent. Organic Letters, Vol. 6, No. 21, pp. 3809-3812, ISSN 1523-7060 


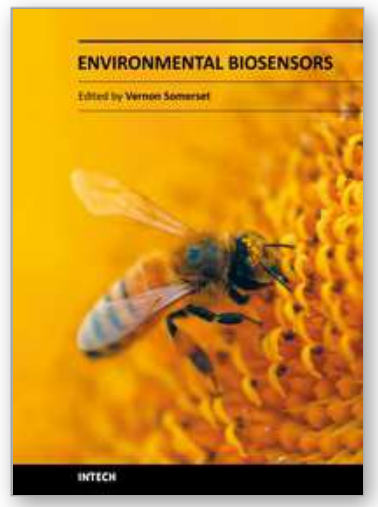

\author{
Environmental Biosensors \\ Edited by Prof. Vernon Somerset
}

ISBN 978-953-307-486-3

Hard cover, 356 pages

Publisher InTech

Published online 18, July, 2011

Published in print edition July, 2011

This book is a collection of contributions from leading specialists on the topic of biosensors for health, environment and biosecurity. It is divided into three sections with headings of current trends and developments; materials design and developments; and detection and monitoring. In the section on current trends and developments, topics such as biosensor applications for environmental and water monitoring, agroindustry applications, and trends in the detection of nerve agents and pesticides are discussed. The section on materials design and developments deals with topics on new materials for biosensor construction, polymerbased microsystems, silicon and silicon-related surfaces for biosensor applications, including hybrid film biosensor systems. Finally, in the detection and monitoring section, the specific topics covered deal with enzyme-based biosensors for phenol detection, ultra-sensitive fluorescence sensors, the determination of biochemical oxygen demand, and sensors for pharmaceutical and environmental analysis.

\title{
How to reference
}

In order to correctly reference this scholarly work, feel free to copy and paste the following:

Monika Hoskovcova and Zbynek Kobliha (2011). Modified Cholinesterase Technology in the Construction of Biosensors for Organophosphorus Nerve Agents and Pesticides Detection, Environmental Biosensors, Prof. Vernon Somerset (Ed.), ISBN: 978-953-307-486-3, InTech, Available from:

http://www.intechopen.com/books/environmental-biosensors/modified-cholinesterase-technology-in-theconstruction-of-biosensors-for-organophosphorus-nerve-agen

\section{INTECH}

open science | open minds

\section{InTech Europe}

University Campus STeP Ri

Slavka Krautzeka 83/A

51000 Rijeka, Croatia

Phone: +385 (51) 770447

Fax: +385 (51) 686166

www.intechopen.com

\section{InTech China}

Unit 405, Office Block, Hotel Equatorial Shanghai

No.65, Yan An Road (West), Shanghai, 200040, China

中国上海市延安西路 65 号上海国际贵都大饭店办公楼 405 单元

Phone: +86-21-62489820

Fax: $+86-21-62489821$ 
(C) 2011 The Author(s). Licensee IntechOpen. This chapter is distributed under the terms of the Creative Commons Attribution-NonCommercialShareAlike-3.0 License, which permits use, distribution and reproduction for non-commercial purposes, provided the original is properly cited and derivative works building on this content are distributed under the same license. 